\title{
Class Versus Industry Cleavages: Inter-Industry Factor Mobility and the Politics of Trade
}

\author{
Michael J. Hiscox
}

\section{Introduction}

The expansion of international trade has been a powerful engine driving economic growth in Western nations over the last two centuries. At the same time, it has provoked an enormous amount of internal political conflict, since trade has disparate effects on different sets of individuals within an economy. Although conflict between "winners" and "losers" has been a constant in trade politics, the character of the political coalitions that have fought these battles-the nature of the societal cleavages that the trade issue creates-appears to have differed significantly across time and place.

Consequently, the literature on the political economy of trade has developed something of a split personality. Many scholars, following in the grand tradition of E. E. Schattschneider, have focused on the political role of narrow industry groups or "special interests" in the policymaking process." This approach has been prominently adopted by Peter Gourevitch and is common to quantitative studies of trade barriers inspired by the "endogenous policy" literature in economics. ${ }^{2}$ In contrast, Ronald Rogowski has famously examined broad factoral or class coalitions in a range of historical contexts, highlighting political conflicts among owners of land, labor, and capital over the direction of trade policy. ${ }^{3}$ Other analysts, drawing distinctions between owners of multinational and other types of capital, or between

An earlier version of this article was presented at the 1995 Annual Meeting of the American Political Science Association in Chicago. I thank Jim Alt, Carles Boix, Lawrence Broz, Jeff Frieden, Mike Gilligan, Peter Gourevitch, Douglas Irwin, David Lake, Ron Rogowski, Cheryl Schonhardt-Bailey, Verity Smith, Daniel Verdier, and two anonymous reviewers for helpful comments.

1. Schattschneider 1935 .

2. Gourevitch 1986. See also, for example, Anderson 1980; Lavergne 1983; and Baldwin 1985.

3. Rogowski 1989. 
skilled and unskilled labor, have made similar assumptions about the centrality of class cleavages in trade politics. ${ }^{4}$

Empirical evidence suggests support for both approaches. The lobbying free-forall among industry groups that led to the U.S. Smoot-Hawley Tariff Act in 1930 lives in infamy, and most accounts of contemporary U.S. trade politics indicate that such groups have played a prominent role in recent battles over the North American Free Trade Agreement and the General Agreement on Tariffs and Trade (GATT). Historical accounts of trade politics in a variety of nations-in particular, France during the nineteenth century —reveal that these kinds of industry-based cleavages have a long and robust ancestry. ${ }^{5}$ But examples of class-based cleavages are also familiar to most readers. Perhaps most famously, workers in nineteenth-century Britain, taking on the ruling Tories and the landed elite, aligned with capitalists to provide mass support for freer trade and the Anti-Corn Law League. A similar kind of contest developed in the United States after the Civil War-this time between pro-trade farmers and protectionist urban classes- and led to a Republican tariff in 1890 that was denounced by Democrats as the "culminating atrocity of class legislation."

That both class and group approaches have found empirical support in a variety of contexts suggests the need for a way to bridge the gulf between them that would specify the conditions under which one is more appropriate than the other. To this end I apply the standard economic theory of trade to highlight the importance of inter-industry factor mobility - that is, the ease with which owners of factors of production (land, labor, and capital) can move between industries in the domestic economy. If factors are mobile between industries, the income effects of trade divide individuals along class lines, setting owners of different factors (such as labor and capital) at odds with each other regardless of the industry in which they are employed. If factors are immobile between industries, the effects of trade divide individuals along industry lines, setting owners of the same factor in different industries (labor in the steel and aircraft industries, for example) at odds with each other over policy.

I survey evidence on levels of inter-industry factor mobility in six Western economies (the United States, Britain, France, Sweden, Canada, and Australia) during the nineteenth and twentieth centuries. ${ }^{6}$ The available data indicate that substantial variation in factor mobility coincides with different stages of industrialization and different amounts of regulation. The patterns in this variation, and their anticipated effects, fit broadly with the development of trade politics in these nations during different historical eras. I report findings from a study of the trade cleavages in each nation that emphasizes the effects of such cleavages on the behavior of political parties and peak associations and the lobbying efforts of major industry

4. See Helleiner 1977; and Midford 1993.

5. Smith 1980.

6. These nations are particularly attractive candidates for close study since they have long histories of democratic government and the political disputes over trade in each have been well documented. 
groups. ${ }^{7}$ The results indicate that broad class-based conflict is more likely when levels of factor mobility are relatively high, and narrow industry-based conflict is more likely when levels of mobility are relatively low. I next describe the economic models that make a focus on inter-industry factor mobility appropriate. I then present evidence indicating substantial changes in levels of labor and capital mobility in the six Western nations over the last two centuries. I survey evidence on trade cleavages and coalitions in each nation in different historical eras. In the conclusion I discuss implications of this analysis for trade policy and consider qualifications and alternative hypotheses.

\section{Trade Theory, Coalitions, and Factor Mobility}

According to the Stolper-Samuelson theorem, trade increases real returns for owners of the factor of production with which the economy is relatively abundantly endowed, while it reduces real returns for owners of the scarce factor of production. ${ }^{8}$ The result depends critically on the assumption that factors of production, though immobile internationally, are perfectly mobile within the domestic economy. ${ }^{9}$ The logic is straightforward: increased trade lowers the price of the imported good, leading to a reduction in its domestic production and freeing up more of the factor it uses relatively intensively (the scarce factor) than is demanded elsewhere in the economy at existing prices. When factor prices adjust to maintain full employment, returns to the scarce factor fall even further than the price of the imported good; meanwhile, returns to the abundant factor rise even further than the price of the exported good. In this model the perfect mobility of the factors assures that trade affects owners of each factor in the same way no matter where they are employed in the economy. The implication is that all owners of the same factor share the same preferences with respect to trade policy. It is this insight that encouraged Rogowski to argue that trade coalitions form in the shape of broad factor-owning classes and to anticipate broad-based conflict among owners of land, labor, and capital in trade politics. ${ }^{10}$

Alternative models of the income effects of trade (often referred to as Ricardo-Viner models), in which one or more factors of production are regarded as completely immobile between industries, generate very different results. ${ }^{11}$ In these models the

7. For the full study, see Hiscox 1997 and forthcoming.

8. Stolper and Samuelson 1941.

9. Factors are identified as broad categories of productive inputs and include at least labor and capital. Whereas traditional Heckscher-Ohlin studies of trade focus on land, labor, and capital, Leamer has defined eleven separate factors: capital, three types of labor (professional, semiskilled, and unskilled), four types of land (tropical, temperate, dry, and forested), coal, minerals, and oil. Leamer 1984.

10. Rogowski 1989. Classes are defined here simply in terms of factor ownership: each class comprises those individuals well endowed with a factor relative to the economy as a whole; this definition allows for the fact that individuals often own a mix of factors. See Mayer 1984.

11. See Jones 1971; and Mussa 1974 and 1982. The original model was introduced independently by Jones and Samuelson; Jones christened it the "specific-factors" model, and Samuelson named it the "Ricardo-Viner" model. See Jones 1971; and Samuelson 1971. 
returns to "specific" factors are tied closely to the fortunes of the industry in which they are employed. Factors specific to export industries receive a real increase in returns due to trade, whereas those employed in import-competing industries lose in real terms. ${ }^{12}$ Under these conditions, factor specificity can drive a wedge between members of the same class employed in different industries since they can now be affected quite differently by trade. The implication is that political coalitions form along industry lines. This notion has guided much of the empirical analysis in the endogenous trade policy literature, which relates variation in import barriers across industries to the incentives and capacities of industry groups to organize. ${ }^{13}$

Both Stolper-Samuelson and Ricardo-Viner models examine extreme, or polar, cases in which productive factors are assumed to be either perfectly mobile or completely specific. ${ }^{14}$ This is a modeling convenience, of course. Factor mobility is more appropriately regarded as a continuous variable, affected by a range of economic, technological, and political conditions. Allowing that factors can have varying degrees of mobility, the simple prediction is that broad class-based political coalitions are more likely where factor mobility is high, whereas narrow industrybased coalitions are more likely where mobility is low. The trade issue should divide societies along very different lines when substantial variation exists in levels of factor mobility.

\section{Evidence of Changing Levels of Factor Mobility}

\section{Measuring Levels of Factor Mobility}

To test the plausibility of the argument, I consider developments in the United States, Britain, France, Sweden, Canada, and Australia over the last two centuries. To date, analysts in the trade politics literature have not examined the empirical evidence on mobility in a systematic fashion. Some indirect evidence on mobility has been supplied by studies of the revealed preferences of industry groups and individuals in politics. ${ }^{15} \mathrm{I}$ have relied here principally on measurements of the difference between rates of return for factors employed in different industries (specifically, on the coefficients of variation for wage and profit rates across

12. Again, the logic is straightforward: a decrease in the domestic production of an imported good releases any mobile factors for employment elsewhere in the economy and thus renders factors specific to the import-competing industry less productive, driving down their real returns. Returns to the mobile factor rise relative to the price of the imported good but fall relative to the price of exports, so that the income effects of trade for owners of this factor depend on patterns of consumption.

13. For example, Anderson 1980; and Lavergne 1983.

14. In the economics literature, the bifurcation is considered unproblematic since specific-factors effects are generally regarded as important in the short term but not the long term. See Mussa 1974; Caves, Frankel, and Jones 1990, 146-49; and Krugman and Obstfeld 1987, 81. It is simply assumed that, over time, all factors are perfectly mobile. The problem with this view lies in its neglect of politics: factor owners not only choose between accepting lower returns in one industry or moving to another; they can also organize politically to influence policy and alter relative prices.

15. The most-cited example is Magee's study of group testimony before the U.S. House Ways and Means Committee on the Trade Act of 1974. Magee 1980. Irwin examined county voting patterns in the British general election of 1923. Irwin 1995. 
industries). If a factor is highly mobile, rate-of-return differentials should be arbitraged away by factor movement. Smaller differentials indicate higher mobility. Different versions of this type of measure have been used previously in studies of labor mobility and in recent studies of international capital mobility. ${ }^{16}$ Where possible, I compared results based on these measures with other indicators of mobility, such as the rate of turnover in labor markets and spending by firms on research and development and worker training. ${ }^{17}$

Overall, the evidence suggests that inter-industry factor mobility has been powerfully affected by economic and technological changes associated with industrialization. Yet the impact of those changes, and their timing, has varied substantially across nations. Figure 1 reports available data on inter-industry variation in wage and profit rates for each nation.

For the first half of the nineteenth century, the only extensive data available are hourly wage rates for skilled labor (artisans or tradesmen), including carpenters, spinners, weavers, masons, smiths, machinists, and so on. ${ }^{18}$ For later years, we have data on wages for separate categories of skilled and unskilled workers in major manufacturing industries (at the two-digit SIC level) from which to calculate coefficients of variation. ${ }^{19}$ Data on profits, calculated as value-added minus wage costs per man-hour in each industry, are scarce until the 1940 s but widely available thereafter, and we have some direct data on corporation profits. ${ }^{20}$

The temporal trends in the data are immediately apparent in all six economies. Again, recall that lower coefficients of variation indicate higher levels of inter-

16. See, for example, Krueger and Summers 1988; and Frankel 1992. Inter-industry wage and profit differentials are not perfect measures of mobility, of course. They may sometimes reflect other features of factor markets besides underlying mobility levels, including regulations on wages and profits, and wage bargaining arrangements. But the consequences are unlikely to be dire for making predictions about the trade policy preferences of factor owners. Factor mobility is important to the coalition story precisely because it plays a key role in determining the generation of industry rents, and wage and profit differentials are the clearest measure of whether such rents actually exist.

17. A basic problem with using indicators of "flows" or factor movements, such as turnover in labor markets, is that there are no controls for the incentives to move. Factor owners may find movement relatively cheap, but they have little incentive to move if return differentials are low. In the highly integrated international bond markets, for instance, returns on securities are equalized with minimal trading activity. Frankel 1992.

18. For a more comprehensive discussion, see Hiscox 1997 and forthcoming. For data sources, see the appendix.

19. Only very basic controls have been applied here for labor skills, so much caution is required. The results may be reflecting changes in skill mixes or working conditions across industries, not changes in underlying mobility. However, Krueger and Summers have shown that controlling for skill and working conditions in econometric wage equations (using survey data for individual workers) is not important for estimating the relative size of differentials over time. Controlling for finely described skill differences reduces the size of the estimated industry rents across the board but does little to alter the relative size of measured differentials at different times. Krueger and Summers 1987.

20. There are no controls here for cross-industry differences in risk. Changes in profit dispersion might be reflecting changes in the relative riskiness of investment in different industries. However, I found similar results using measures of profits disaggregated to the four-digit SIC level and estimating profit equations to measure variation between the two-digit industries while controlling for risk (measured by variability in returns over time). Hiscox 1996. 


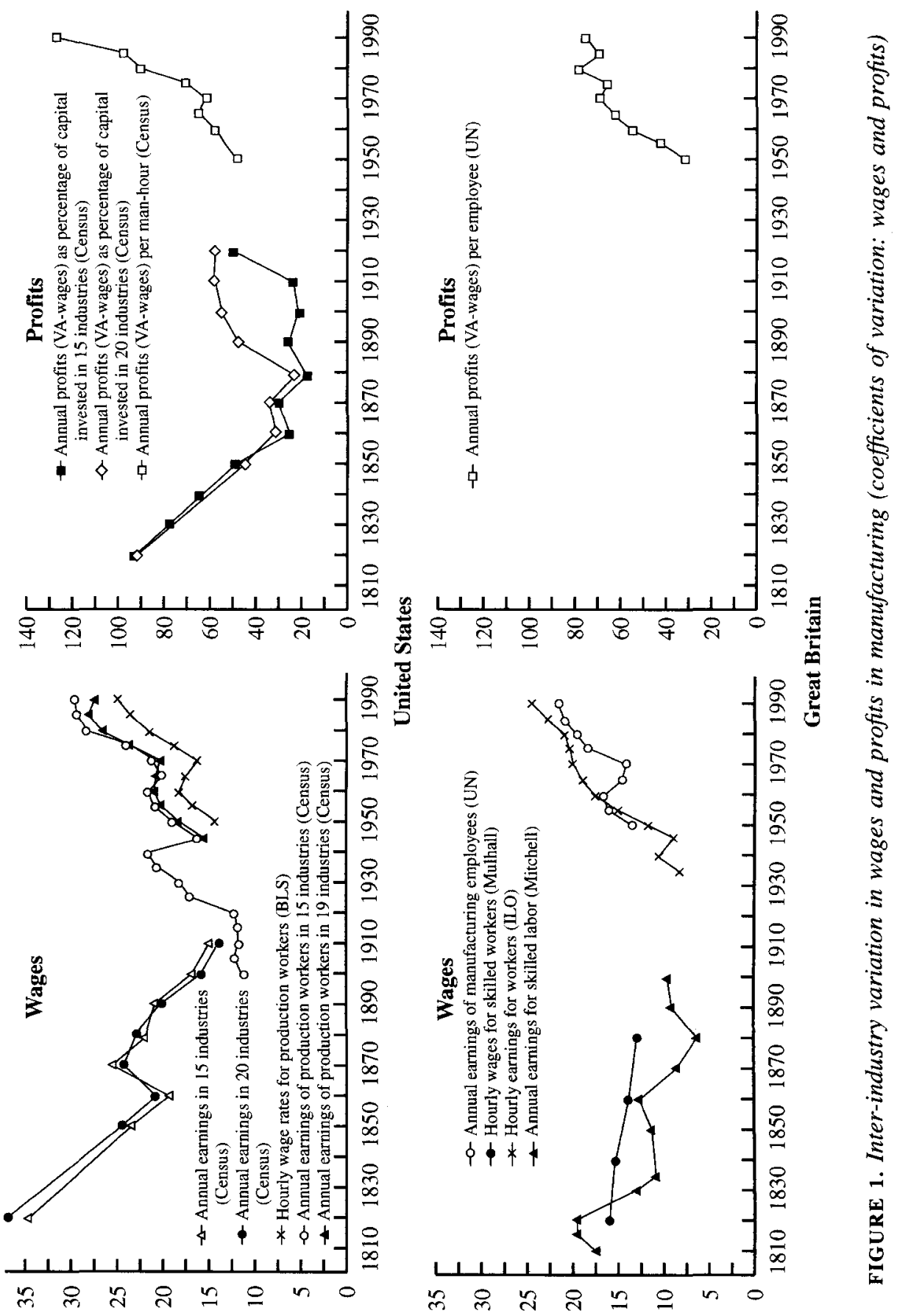




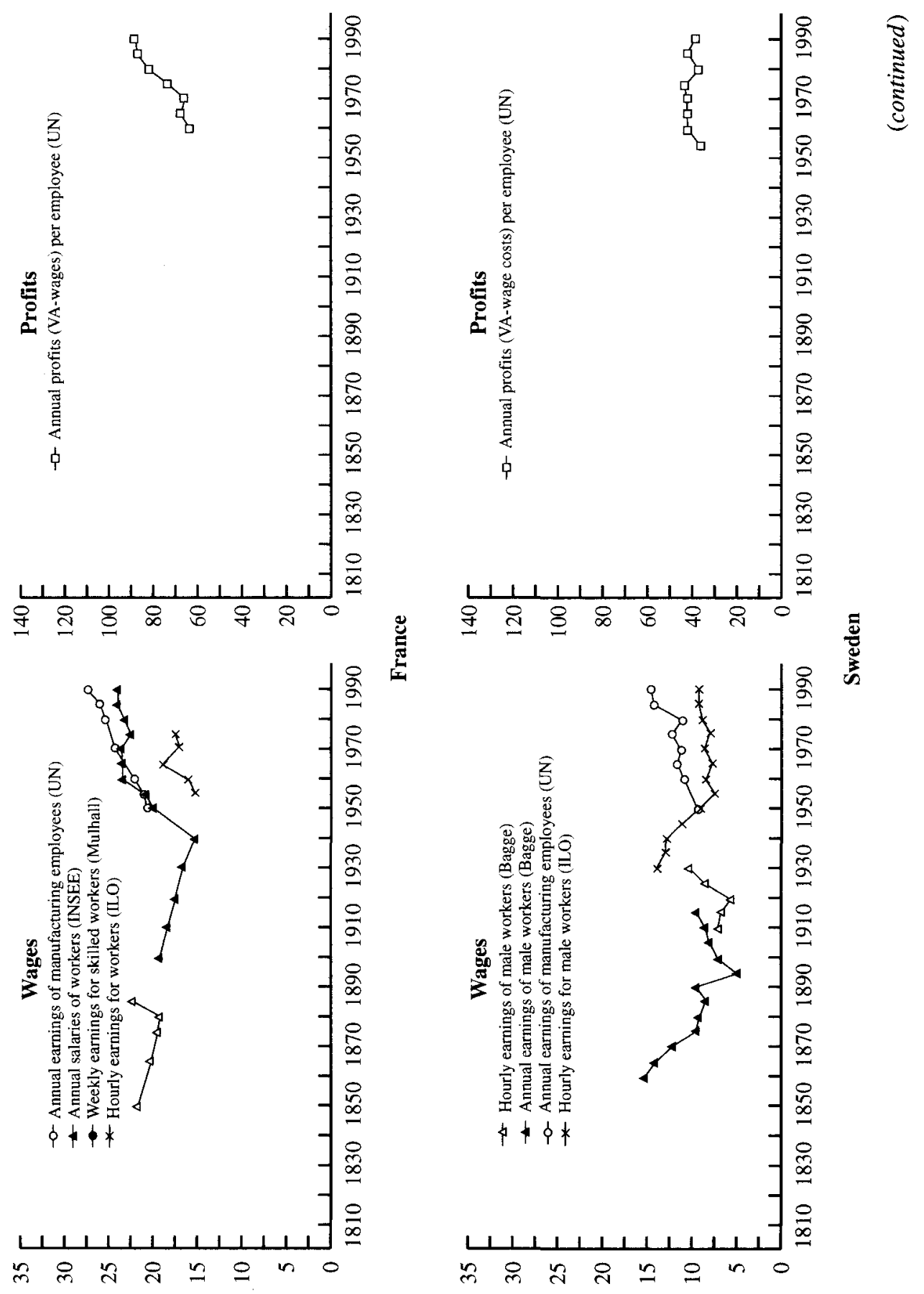




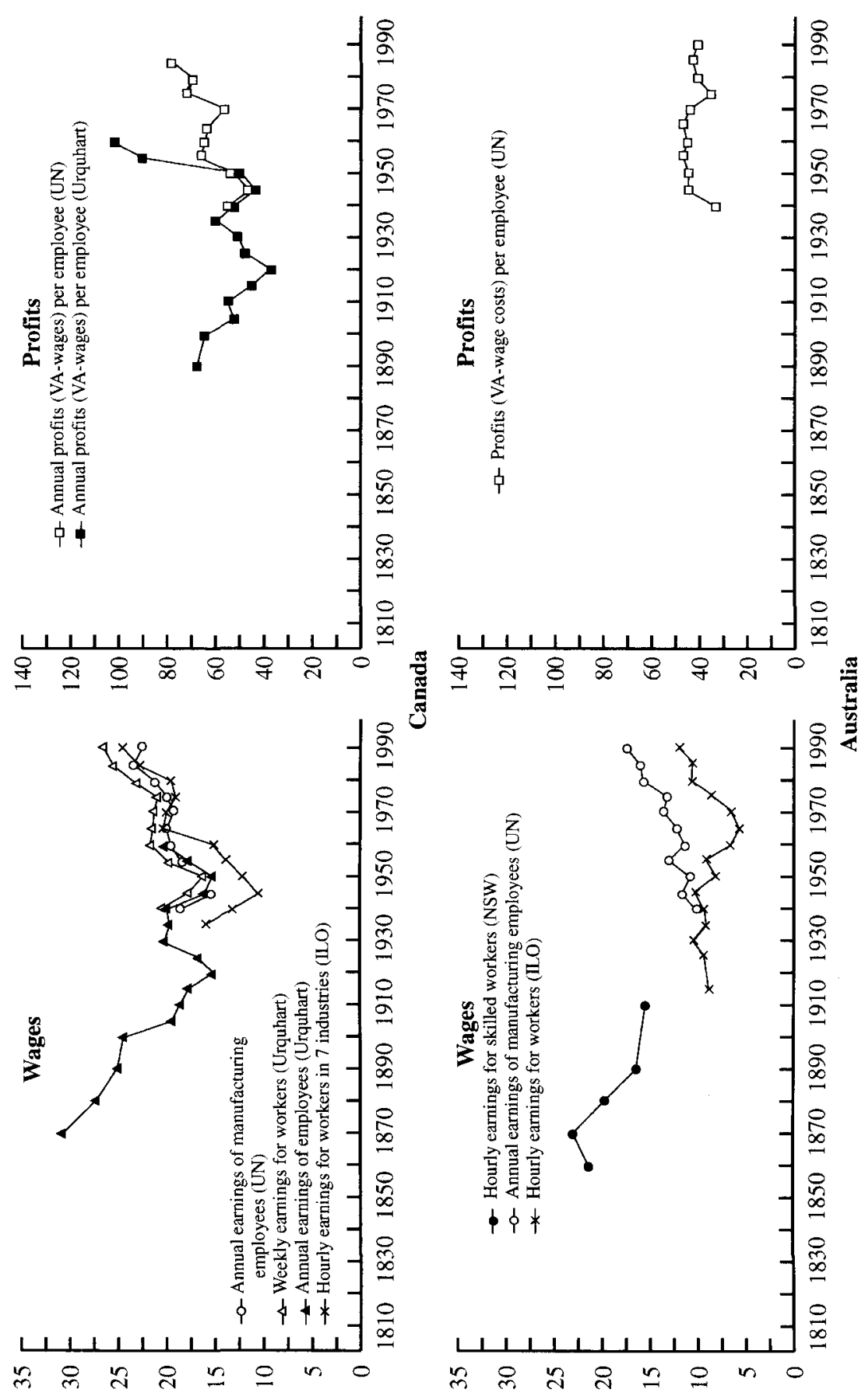


industry mobility. Consider first the changes in the coefficients during the nineteenth century. In the first half of the century wage differentials appear to be generally high (relative to those in later years) but falling. Though the data on profits are more scarce, a similar pattern is described by inter-industry variation in profit rates. The trends indicate a general and steady rise in levels of inter-industry factor mobility through most of the nineteenth century.

Just as interesting are the cross-national differences in this period. Far higher levels of both labor and capital mobility (that is, lower coefficients of variation) are evident in Britain, where industrialization proceeded most rapidly, than in France, where a heavier legacy of industrial regulation remained. Wage differentials were initially much higher in the United States than in Britain early in the nineteenth century but fell much more dramatically over time. In the smaller nations of Sweden, Canada, and Australia, which lagged behind the others in industrialization, inter-industry return differentials still remained relatively high in the $1860 \mathrm{~s}$, and changes are only clearly apparent late in the century.

By the turn of the century, inter-industry wage and profit differentials had fallen to historically low levels for all six nations. Differentials reached the lowest levels in the United States and Britain, which were leading the other nations in industrial development, and wage variation was still twice as high in France as in Britain at century's end. But changes were most apparent around this time in Sweden and Australia, which actually had the lowest levels of wage variation in the sample by 1914. Higher differentials persisted in Canada, where factor markets were separated, notoriously, into distinct regional economies (though the data are scarce).

By the 1920 s and 1930s, the evidence indicates that the long-term decline in inter-industry wage and profit differentials had come to a halt. Wage and profit differentials even began to rise in some nations - mostly clearly, in the United States. There was, of course, considerable turmoil in factor markets with the onset of the Depression. By the 1950s and 1960s, however, the turnaround in historical trends was more apparent: the data show that industry rents were clearly rising in all six economies. ${ }^{21}$ Again, there are some marked cross-national differences. A particularly sharp rise in wage and profit differentials occurred in the United States and Britain after the 1940s; in Sweden and Australia, by contrast, the evidence indicates a much slower rise in inter-industry wage and profit variation from the very low levels attained early in the century. The lowest levels of wage variation in the postwar period are found in Sweden. ${ }^{22}$ These no doubt reflect the "solidarity"

21. These conclusions are supported by the available data on labor turnover. In fact, the postwar decline in turnover prompted concern among labor economists about a "new industrial feudalism" in the 1950s. See Ross 1958. For analysis of the downward trend in tumover in the United States and elsewhere, see Ragan 1984; and Holmlund 1984.

22. Edin and Zetterberg draw a similarly sharp contrast between Sweden and the United States, concluding that wage differentials are roughly three times larger in the United States than in Sweden. Edin and Zetterberg 1992. Lawrence and Bosworth found the same results when testing claims that wage solidarity and welfare policies had rendered the Swedish economy "inflexible" in the face of economic shocks. They found instead that employment and output changes by industry in the $1970 \mathrm{~s}$ and $1980 \mathrm{~s}$ 
wage policy that was the heart of the Rehn-Meidner approach to centralized wage negotiations during most of this period as well as Sweden's extensive adjustment assistance program. ${ }^{23}$

\section{Sources of Change and Cross-National Variation}

The general correspondence between changes in inter-industry wage and profit differentials is consistent with the notion that broad exogenous technological and regulatory changes have led to the observed shifts. ${ }^{24}$ And the specific, implied changes in levels of inter-industry factor mobility fit with some prevailing wisdom about the effects of economic development on factor markets. Economic historians, for instance, have frequently discussed the lifting of legal restrictions on factor movement that was a common, though by no means uniform, concomitant of early industrialization, and they widely cite England's head start in deregulationtraceable as far back as the Statute of Artificers in $1563 .{ }^{25}$ Historians have also described the way in which, in the early stages of industrialization in the nineteenth century, major innovations in transportation drastically lowered the costs of factor movement and diminished the importance of geography to economy. ${ }^{26}$ Again, England led the pack with its efficient canal system and turnpike roads and the first railway mania. ${ }^{27}$ Change was more gradual in the sprawling United States, where inland freight rates only began to fall along roads and rivers beginning in the $1820 \mathrm{~s}$, along canals beginning in the $1830 \mathrm{~s}$, and along the new railroads from the $1850 \mathrm{~s}^{28}$ In Sweden, Canada, and Australia, rapid construction of railroads took place much later in the century. ${ }^{29}$

The effect was that production became less concentrated by region and more subject to integrated commodity and input markets. ${ }^{30}$ In particular, land owners could put farms to a wider range of alternative uses as distance from markets

revealed that the pace of resource allocation was more rapid in Sweden than in the United States, Germany, and Japan. Lawrence and Bosworth 1987.

23. See Lundberg 1985; Hibbs and Locking 1996; and Lindbeck 1974. But for reasons stated earlier (see note 17), the distinction is not crucial. The bottom line is that, as Rivlin points out, Swedish workers in high wage industries like steel did not face reductions in living standards comparable to those faced by steel workers in the United States if laid off, since the wages of U.S. steel workers were much higher compared to average U.S. wages than were the Swedish steel workers' wages compared to average Swedish wages. Rivlin 1987, 13-14.

24. The correspondence is also broadly consistent with "rent sharing" between capital and labor. See Katz and Summers 1989. The generally higher variation in profits across industries fits with the standard modeling assumption that physical capital tends to be more specific to use than human capital.

25. See Landes 1969, 62; North and Thomas 1973; and Olson 1982.

26. See Taylor 1951; Davis, Hughes, and McDougall 1961, 276-96; and North 1965.

27. See Pratt 1912; and Clapham 1926-38, 94.

28. North 1965. The miles of railway track in operation rose from 30,626 to 166,703 between 1870 and 1890. Martin 1992.

29. Heckscher 1954, 213.

30. O'Brien 1983. 
became less important. ${ }^{31}$ Although we have no detailed data on farm incomes with which to measure the inter-industry mobility of agricultural producers, it seems likely that they were affected profoundly. Production of meat and perishable farm goods, for instance, could be extended to areas much further from urban markets after the arrival of the railway; innovations in refrigerated transportation reinforced this trend. General improvements in irrigation and artificial fertilizers, most apparent in the late $1800 \mathrm{~s}$, also helped to make agricultural production more flexible. ${ }^{32}$ Notice, too, that farmers can effectively move between industries, not only by switching their land to alternative uses but also by moving themselves to take up new land suited to alternative production. And in the United States, Canada, and Australia vast areas of different types of land were being taken over at this time by large numbers of settlers flexible about what they would cultivate.

Technological innovations in methods of production in the nineteenth century also had profound implications for inter-industry factor mobility. The very heart of the industrial revolution, of course, was the interrelated succession of technological changes that substituted machine manufacture for handicraft production and revolutionized the manufacture of textiles, iron and steel, and steam power, first in England and then elsewhere. ${ }^{33}$ New mills and factories replaced craft shops and home manufacture, and the old skills of the artisan class were rendered increasingly obsolete. A second cluster of innovations in the manufacture of electric power and electrical machinery and internal combustion engines brought assembly-line production and precision manufacturing, and the great shift from nodal to linear flow manufacturing swept through industry in the last two decades of the nineteenth century. ${ }^{34}$ Much of the new technology provided new ways to pipe, pump, lift, convey, shape, press, heat, and measure raw materials and was readily adaptable to use in alternative industries. ${ }^{35}$ These developments created a vast demand for unskilled workers and increased the ease with which industrial workers could shift between manufacturing industries. ${ }^{36}$

However, the apparent decline in inter-industry mobility in these economies beginning in about the 1920s (the timing varies by nation) was most likely due to the growing complementarity between labor skills and technology. ${ }^{37}$ Whereas the key technological advances of the nineteenth century had substituted new physical capital, raw materials, and unskilled labor for skilled workers, later advances began to demand specialized forms of human capital to go with the new forms of physical capital. ${ }^{38}$ Claudia Goldin and Lawrence Katz argue that the key change in U.S.

31. Rogowski 1989, 19.

32. Heckscher $1954,176$.

33. Landes 1969.

34. See Landes 1969, 305-307; and Sawyer 1954.

35. Landes 1969, 293-94.

36. Sokoloff 1986.

37. On skill-technology complementarity, see Griliches 1969; Hamermesh 1993; Bartel and Lichtenberg 1987; and Fallon and Layard 1975.

38. See Cain and Paterson 1986; James and Skinner 1985; and Sokoloff 1984. 
industry took place in the 1910 s and 1920 s and involved moving from assembly line to continuous-process technology - the latter requiring more skilled workers in the management and operation of highly complex tasks. Growth in the demand for human capital, or knowledge and skills, has been concomitant with continued technological improvements since that time. ${ }^{39}$ Studies have revealed a clear inverse relationship between investments in industry and firm-specific human capital and labor mobility. ${ }^{40}$

Viewed in this light, the recent downward trend in inter-industry worker mobility, and the upward trend in wage differentials, makes considerable sense. ${ }^{41}$ Concurrent with a growing emphasis on specialized human capital has been the increasing importance placed on specialized physical capital and knowledge. There has been a huge increase in spending on research and development by firms. ${ }^{42}$ In addition, as Caves and Porter have argued, barriers to exit and entry for firms have risen with higher start-up costs and increased investments in physical capital associated with the general growth in the scale of production. ${ }^{43}$ Whereas the evidence is not strong that economies of scale alone act as powerful barriers to entry, ${ }^{44}$ more evidence indicates that larger capital requirements result in fewer individuals or groups being able to secure the funding needed for entry, and then only at interest rates that place them at a cost disadvantage. ${ }^{45}$

\section{Coalition Patterns in Trade Politics}

In light of the evidence that levels of inter-industry factor mobility have varied substantially both across nations and within each economy over time, the question

39. See Goldin and Katz 1996; and Mincer 1984. One crude indicator of the trend in the United States is that the ratio of nonproduction to production workers grew from 0.05 in 1900 to 0.13 in 1929 , and to 0.35 in 1970. U.S. Department of Commerce, Historical Statistics. The ratio of "professional and technical" employees to production workers, as measured by the International Labor Organization, grew from 0.30 in 1960 to 0.64 in 1990 (ILO, Yearbook of Labour Statistics).

40. See Bloch 1979; Parsons 1972; and Ragan 1984. A large part of the story here is that, because the cost of quitting has increased for employers, the rational response has been to encourage longer tenure among employees. The general expansion in the use of fringe benefits tied to seniority and its negative impact on mobility have been much discussed. See Oi 1962; Block 1978; and Mitchell 1982.

41. Apart from the technological forces at work, several other changes have been identified as having had a negative effect on factor mobility in the postwar era. The growing number of two-income families, unionization, greater progressivity in taxes, and the introduction of sick-leave and maternity policies have all beè identified as changes rendering job change generally less attractive to workers. See Holmlund 1984; and Freeman 1976 and 1980.

42. Spending by U.S. manufacturing companies on R\&D (as a percentage of sales) rose from 0.5 percent in 1950 to 3 percent in 1990. U.S. Department of Commerce, Statistical Abstract. The first industry laboratory in the United States was established by General Electric in 1900; by 1931, some 1,600 U.S. companies reported research labs. See Reich 1985, 2; and Galambos 1979.

43. Caves and Porter 1979.

44. Scherer 1980.

45. See Hay and Morris 1984; and Geroski and Jacquemin 1985. Strategic considerations also play a role here. Since exit by one firm can increase the profitability of others when scale economies are large, each firm has an incentive to "out wait" the other, even in the face of persistently low returns. Ghemawat and Nalebuff 1990. 
remains whether this variation has produced observable changes in trade coalitions that are consistent with our expectations. According to the argument advanced earlier, broad factor-owning class coalitions were more likely to form when factor mobility was high, whereas narrow industry-based coalitions were more likely to form when mobility was low.

How exactly would we recognize such differences in coalition patterns? What are their observable implications? The term coalition implies more than just a set of individuals with shared policy preferences; it implies some form of political activity (such as voting, lobbying, protesting, or threatening to do any of these) that is aimed at influencing policy. In democratic systems the primary organizational channels through which coalitions of individuals influence policy are political parties, peak associations, and lobby groups. These are the logical places to look for inferences about coalition patterns.

What can we infer from the behavior of political parties in trade politics? The clearest signals will be broadcast when parties are closely associated with particular factor-owning classes-broad categories of workers, capitalists, or farmers. This has often been the case for the major parties in Western democracies. ${ }^{46}$ The British Labour and Australian Labor parties are prime examples of parties tied closely to the workers and the trade union movement, as are the French Socialists and Communists. The old Agrarian party in Sweden, and the Country party (now National party) in Australia, are good examples of parties with "re-election constituencies" consisting mainly of farmers.

In such cases linking party behavior in trade politics to coalition patterns is a simple matter. We can map the class preferences over trade (derived from the Stolper-Samuelson theorem) onto a model of partisan politics. All else constant, the stronger the class cleavages over trade, the more unified the parties representing factor-owning classes on either a protectionist platform (when representing scarce factors) or a free-trade platform (when representing abundant factors). According to our theory, at high levels of factor mobility, Stolper-Samuelson effects should ensure that whole factor classes have more unified views on trade and this should favor party unity. At low levels of mobility, Ricardo-Viner effects will create divisions between owners of the same factor in export and import-competing industries, dividing party constituencies and party representatives in legislatures - who will have very different calculations of the net utility associated with supporting a policy change depending

46. Indeed, traditional theories of party systems locate the origins of modern parties in the national and industrial revolutions that created sharp divisions between urban and rural interests and between capitalists and workers. See Lipset and Rokkan 1967. And much recent work in comparative political economy, in fact, has revealed a firm link between major parties and distinctive class constituencies in the formulation of economic policy. See Hibbs 1977; Lange and Garrett 1985; Alesina 1989; and Alesina and Rosenthal 1995. 
on which industries assume the greatest importance in their particular electoral districts. $^{47}$

For parties that are not so clearly aligned with particular factor-owning classes and instead have diverse economic constituencies centered around religious, ethnic, or regional groupings, we can make few, if any, inferences about trade coalitions. ${ }^{48}$ There is also the possibility that parties may have core constituencies that include more than one factor-owning class. This will pose a problem if the included classes comprise owners of both abundant and scarce factors: we would then expect that the party would always be divided internally over trade--by a class cleavage when levels of mobility are high, and by industry cleavages when mobility is low. ${ }^{49}$

The presumption here is that the trade issue itself, and the cleavages it generates, is not sufficient to transform the existing party system. If trade were the only issue, we could expect that two parties would always take up unified and opposing platforms; they might reflect class-based coalitions when mobility levels were high, or industry-based coalitions when mobility was low. Changes in levels of mobility would simply induce partisan realignment around the new cleavage. Although trade has often been a highly partisan issue, it has seldom (if ever) generated new party systems or partisan realignments itself. ${ }^{50}$ The working assumption here is that party systems are the exogenous product of deeper-seated urbanrural, Left-Right, church-state, ethnic, or regional cleavages, in combination with electoral institutions. ${ }^{51}$

We face fewer problems in interpreting evidence about the behavior of encompassing or peak associations. The class affiliations of confederations of labor unions, business associations, and farm organizations are clearly delineated. ${ }^{52}$ We can simply map onto these associations the class preferences derived from trade theory. All else constant, we expect such associations to be more unified in support of coherent protectionist (scarce factors) or free trade (abundant factors) the stronger

47. Note that the extent to which the trade issue divides legislative parties under these conditions should be an increasing function of the degree to which production is concentrated geographically.

48. The Bonapartists and clericalists in the French Third Republic are good examples, along with the Ministerials in Sweden after the reform of the Riksdag in 1866. The Parti quebecois in modern Canada is a more familiar example of a regional party.

49. The best (perhaps only) example is the anti-labor "Liberal" party in Australia, formed in 1909 by a merger between the Free Trade Party (representing rural interests) and the Protectionists (representing urban business).

50. Again, the Australian case provides one example: national Free Trade and Protectionist parties competed (along with Labor) after federation in 1901. As noted, however, the trade issue was quickly overwhelmed by more rudimentary class issues (taxation, welfare, nationalization, labor regulation) and the two parties joined forces to confront Labor.

51. For a discussion of the debate about the relationship between cleavage structures and party systems, see Cox 1997, 19-27. Cox argues forcefully that electoral institutions have powerful effects "in interaction with cleavages" in determining party structures.

52. There is often more than one peak association for each factor-owning class, of course. In France, for instance, the non-communist labor union confederation, the Confédération française démocratique du travail, still competes with the older, more radical Confédération générale du travail. 
the class cleavages over trade-that is, according to our theory, the more mobile the factors of production. We should expect, for instance, that national federations of labor unions, like the Trades Union Congress in Britain or the AFL-CIO in the United States, will express firmer and more cohesive positions on the trade issue when labor is more mobile between industries; when levels of mobility fall, the gap between the preferred trade policies of unions in different industries will increase, creating more disagreement.

Finally, what inferences about coalitions can be made based on the behavior of lobby groups? Industry-based labor unions and management associations are the logical modern conduits for industry pressures in trade politics, and we should expect that lobbying by such groups will be shaped by industry preferences (derived in the Ricardo-Viner model). ${ }^{53}$ All else constant, the stronger the industry cleavages over trade, the more active the industry groups in lobbying for protection (in import-competing industries) or for freer trade (in export industries). At low levels of mobility, Ricardo-Viner effects tie factor returns more closely to the fortunes of each industry, giving labor unions and management associations an incentive to lobby for trade policies that will confer rents by either limiting import competition or boosting exports. At high levels of mobility, industry rents are eliminated, and Stolper-Samuelson effects mean that any benefits to be had from lobbying will be dispersed among all other owners of the same factor (that is, they have the nonexcludable quality of a public good). ${ }^{54}$

Table 1 summarizes the anticipated effects of variation in levels of mobility and coalition patterns on the behavior of class-affiliated political parties, peak associations, and group lobbying. For simplicity, variability in levels of factor mobility is rather crudely categorized in Table 1 ; in practice, categorizing an economy in absolute terms (as either closer to the Stolper-Samuelson or to the Ricardo-Viner extreme at any particular time) may be difficult. Relative assessments of mobility levels are much more feasible when considering changes in an economy over time or, perhaps more problematically given the data limitations, when comparing one economy with another. ${ }^{55}$

53. Industry groups, like parties, are here assumed to exist for exogenous reasons (or to be readily formed ad hoc if factor owners in an industry have an incentive to lobby)-that is, collective action problems are in the "ceteris" considered "paribus."

54. This last point exposes a grave bias in Magee's famous "test" of the Stolper-Samuelson theorem. In that test Magee assessed whether labor unions and management associations, when lobbying on trade legislation before Congress in 1974, lined up according to factor or industry interests. Magee 1980. Magee's test improbably requires that industry groups are equally likely to lobby on behalf of their factor class when mobility levels are high as they are when mobility is low and they can win industry-specific rents.

While I am here concerned with general measures of factor mobility in the economy, other analysts have examined individual industries and firms and the specificity of their assets (judged typically by reference to levels of $R \& D$ spending and concentration ratios). Such measures have then been related to the energy with which industries or firms lobby for rents, and there are strong indications that lobbying and mobility are negatively related. See Frieden 1991; and Alt et al. 1999.

55. For simplicity, mobility levels are treated as general to all factors here, since, as the evidence suggests, broad exogenous forces have shaped mobility levels among factors in a very general fashion. 
TABLE 1. Anticipated effects of variation in levels of factor mobility

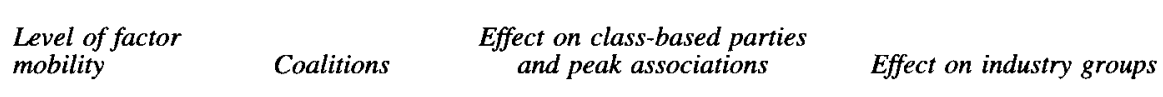

$\begin{array}{lll}\text { Low } \quad \text { Industry coalitions } & \begin{array}{l}\text { Internally divided over trade } \\ \text { issue and adopt ambiguous } \\ \text { policy positions }\end{array} & \begin{array}{l}\text { Lobby actively for protection } \\ \text { in import-competing } \\ \text { industries and for freer trade } \\ \text { in export industries }\end{array}\end{array}$

\begin{tabular}{lll}
\hline High Class coalitions & $\begin{array}{l}\text { Internally unified on the } \\
\text { trade issue and adopt } \\
\text { coherent protectionist (when } \\
\text { representing scarce factors) } \\
\text { or free-trade (abundant } \\
\text { factors) positions }\end{array}$ \\
\hline
\end{tabular}

We can use these simple relationships to assess whether coalition patterns in trade politics appear to have been shaped by changes in levels of factor mobility. To provide for easy comparisons over time, the analysis for each nation is divided into four parts dealing with four reasonably distinct historical periods: $1815-69,1870-1914,1919-39$, and 1945-94; the available evidence on parties, peak associations, and industry groups for each of these periods will be considered. ${ }^{56}$

\section{The United States}

According to the theory, broad factor-owning class coalitions in U.S. trade politics were more likely to form during periods of very high factor mobility (roughly, the late nineteenth and early twentieth centuries). In periods of lower mobility (the early nineteenth and late twentieth centuries) narrow industry-based coalitions were more likely to form.

These anticipated effects are described in Table 2. The table includes the classifications for factor endowments (abundance or scarcity) for each case from Rogowski's 1989 study, which overlaps for almost the entire period covered here. ${ }^{57}$ The data on rate-of-return differentials reported in Figure 1a are used here to distinguish relative levels of mobility in each case. To facilitate comparisons across cases, mobility levels were designated as "high" when the mean coefficient of wage

56. For the full study on which this discussion is based, see Hiscox 1997 and forthcoming.

57. Rogowski used data on industrialization, population, and land area to classify nations according to their relative factor endowments. For the 1945-94 cases I have also referred to recent, more sophisticated empirical work on measuring factor endowments-specifically, the study by Bowen, Leamer, and Sveikauskas 1987. 
TABLE 2. Anticipated and observed outcomes in the United States

\begin{tabular}{|c|c|c|c|c|c|}
\hline Period & $\begin{array}{c}\text { Factor } \\
\text { endowments }\end{array}$ & Mobility & Prediction $^{\mathrm{a}}$ & $\begin{array}{l}\text { Outcomes: Class- } \\
\text { based parties and } \\
\text { associations }\end{array}$ & Industry groups \\
\hline $1815-69$ & $\begin{array}{l}\text { Abundant land; } \\
\text { scarce capital } \\
\text { and labor }\end{array}$ & Low & $\begin{array}{l}\text { Industry } \\
\text { coalitions }\end{array}$ & $\begin{array}{l}\text { Parties split along } \\
\text { regional lines; more } \\
\text { unified in 1850s } \\
\text { with Democrats } \\
\text { opposing Republican } \\
\text { protectionism }\end{array}$ & $\begin{array}{l}\text { Very active; vast } \\
\text { number of } \\
\text { petitions from } \\
\text { groups to } \\
\text { Congress }\end{array}$ \\
\hline $1870-1914$ & $\begin{array}{l}\text { Abundant land; } \\
\text { scarce capital } \\
\text { and labor }\end{array}$ & High & $\begin{array}{l}\text { Class } \\
\text { coalitions }\end{array}$ & $\begin{array}{l}\text { Republicans strongly } \\
\text { favored high tariffs; } \\
\text { Democrats } \\
\text { championed cuts in } \\
\text { tariffs; voting almost } \\
\text { unanimous }\end{array}$ & $\begin{array}{l}\text { Sharp decline in } \\
\text { groups lobbying } \\
\text { congressional } \\
\text { committees up to } \\
\text { turn of century }\end{array}$ \\
\hline $1919-39$ & $\begin{array}{l}\text { Abundant land } \\
\text { and capital; } \\
\text { scarce labor }\end{array}$ & $\begin{array}{l}\text { Intermediate; } \\
\text { falling }\end{array}$ & Mixed & $\begin{array}{l}\text { Parties adhered to } \\
\text { old platforms; some } \\
\text { division among } \\
\text { Democrats with } \\
\text { realignment of labor }\end{array}$ & $\begin{array}{l}\text { Increased } \\
\text { lobbying activity } \\
\text { leading to } \\
\text { Smoot-Hawley } \\
\text { Act in } 1930\end{array}$ \\
\hline $1945-94$ & $\begin{array}{l}\text { Abundant land } \\
\text { and capital; } \\
\text { scarce labor }\end{array}$ & Low & $\begin{array}{l}\text { Industry } \\
\text { coalitions }\end{array}$ & $\begin{array}{l}\text { Parties and peak } \\
\text { associations } \\
\text { internally divided } \\
\text { since } 1950 \text { s and took } \\
\text { ambiguous positions }\end{array}$ & $\begin{array}{l}\text { Active lobbying; } \\
\text { number of } \\
\text { groups testifying } \\
\text { rose swiftly } \\
\text { despite } \\
\text { delegation from } \\
\text { Congress to } \\
\text { executive }\end{array}$ \\
\hline
\end{tabular}

${ }^{a}$ Class coalitions are expected to imply that class-based organizations are internally unified on trade and adopt coherent platforms while groups are inactive. Industry coalitions imply that class-based organizations are internally divided on trade and adopt ambiguous positions (see Table 1).

bUsing 1966 data, Bowen, Leamer, and Sveikauskas (1987) find the United States to be most abundant in arable land and agricultural workers and very abundant in capital; though abundant in professional and technical workers, it is very scarce in all other categories of labor.

variation was greater than 16, "low" when the mean was less than 12 , and "intermediate" otherwise. ${ }^{58}$

The effects anticipated by the theory, based on levels of factor mobility, fit rather well with some stylized facts about U.S. trade politics. The tariff debate was a

58. Since the median mean coefficient for these cases lies between 12.4 and 16.1 , this was the simplest rule that suggested itself. 
predominantly local group-based affair at the beginning of the nineteenth century ${ }^{59}$ In the years after 1815 , memorials from groups poured in to Congress, alternately "praying for" or "remonstrating against" a change in the tariff. ${ }^{60}$ Southern farmers, particularly cotton and tobacco growers reliant on export markets, strongly opposed protection, but farmers growing wool and hemp in the northern and border states advocated higher tariffs. The iron and textile industries of the Northeast were staunch protectionists; but the commercial, shipping, and railroad interests along the Atlantic coast, and manufacturers of products like cotton bagging in the South, strongly supported free trade. These divisions cut across party lines and were reflected in congressional votes on trade legislation that split the parties internally. ${ }^{61}$ Attempts to manipulate these divisions led to the infamous "Tariff of Abominations" in 1828 when Martin Van Buren's plan to use a protectionist bill to split the Adams party went awry as sizeable factions of both parties voted in its favor. ${ }^{62}$ When the Democrats announced the first official party platform in 1839 , they were deliberately vague on the tariff. ${ }^{63}$ Only in the 1840 s did majorities of the two parties assume clearly opposing positions and begin to appeal to broader class-based coalitions. $^{64}$

In the years following the Civil War, the tariff became the partisan issue. The Republicans appealed to urban classes, particularly in the Northeast and Midwest, who had long favored protection, and every one of its platforms after 1860 emphasized the value of a high tariff. ${ }^{65}$ The Democrats' support base was largely agricultural and southern, and from 1876 on, their platforms advocated a tariff

59. See Stanwood 1903, vol. 1; and Pincus 1977.

60. The lobbying came almost exclusively from groups based in particular cities and towns, often representing more than one industry and an assortment of farmers, manufacturers, and workers ("mechanics"). The high costs associated with communications meant that raising a petition on a range of products within a city was still easier than organizing producers of one product in several cities. Pincus 1977, 58.

61. See Taussig 1931, 25-36; and Stanwood 1903, 1:240-43. Average party cohesion indexes for votes on major trade bills in the House (on a hundred-point scale) were only 2.8 (1824), 20.6 (1928), 35.7 (1832), 43.5 (1833), 44.1 (1842), 73.3 (1846), and 59.6 (1857). Although elections still turned mostly on personal contests in the "first" U.S. party system, when the Federalists squared off against Jefferson's Republicans, the development of distinctive national parties with predominantly urban (Adams' Republicans/Whigs) or agrarian (Jackson's Democrats) bases of support was clearer by the early 1830s. Stanwood 1903, 1:240-43.

62. Taussig 1931, 88-98. The apparent aim was to present a bill that would repulse free-trade supporters of Adams in New England while allowing protectionist Jackson supporters in the North and West to be seen as championing tariffs (especially for wool and hemp growers). Southern Jacksonians were persuaded to withhold amendments and assured, mistakenly, that such a bill would be defeated by vote.

63. Stanwood 1903, 2:38.

64. In 1845 southern Democrats held a convention aimed at solidifying an alliance between southern and western agriculturalists in opposition to high tariffs. The Whigs, meanwhile, appealed directly to the labor vote, with the argument linking the tariff to high wages artfully made in numerous articles by Horace Greeley. Commons 1909, 487. In 1856 the Democratic platform finally called for "progressive free trade throughout the world," and in the following year the Republicans openly endorsed protectionism-a position they tied neatly to a defense of the rights of workers and the rejection of the slave labor of the South. Foner 1970.

65. See Rogowski 1989, 44; and Stewart 1991, 218. 
levied for revenue purposes only. ${ }^{66}$ The "long depression" intensified rural demands for tariff reform and remonetization of silver and sparked the Greenback and Granger movements and the Farmers' Alliance. Cleveland fanned the flame of class conflict in 1887 by devoting his entire address to Congress to an attack on Republican protectionism. Thereafter, large partisan swings in policy coincided with each change in control of Congress, and votes on all trade legislation displayed extremely high levels of party cohesion. ${ }^{67}$ When the dispute between Democrats and Populists over silver was finally resolved by "Fusion" in 1896, severing the party's ties to pro-gold supporters in the East, the urban-rural cleavage was placed squarely at the center of U.S. politics. ${ }^{68}$

By the 1920s, however, significant rifts had grown within both parties over the tariff issue. Democrats in Louisiana and Texas were lured away from the party's free-trade position by new agricultural duties on sugar and meat. Republicans in the Midwest and East, influenced by demands from financial interests and export industries, broke ranks and opposed new protectionist bills. Voting on passage of the infamously protectionist Smoot-Hawley Act in 1930 revealed levels of party cohesion lower than any in the United States since the $1870 \mathrm{~s} .{ }^{69}$ Meanwhile, lobbying by industry groups increased dramatically. More groups testified before the House Ways and Means Committee on the SmootHawley bill than on any trade legislation since the Civil War. ${ }^{70}$ In the 1932 campaign, Roosevelt refused to stake out a clear position for the Democrats on trade. ${ }^{71}$ Part of the problem for the Democrats was their growing reliance on support from labor, a traditionally protectionist bloc. Though they pushed through the Reciprocal Trade Agreements Act (RTAA) in 1934, allowing for bilateral negotiations with trading partners, they imposed a range of new import quotas in the $1930 \mathrm{~s}^{72}$

66. Congressional Record, 15 August 1949, 12902. However, an unexpected obstacle for the Democratic tariff reformers in the early $1880 \mathrm{~s}$ was a strong northern component of the party, led by Samuel Randall of Pennsylvania (see Verdier 1994, 73).

67. Average party cohesion indexes for votes on major trade bills in the House were $94.2(1888), 98.7$ (1890), 90.2 (1894), 98.9 (1897), 97.4 (1909), and 94.3 (1913).

68. The American Federation of Labor and the National Association of Manufacturers both strongly endorsed the protectionist Republican platform.

69. Average party cohesion indexes for votes in 1930 were 79.0 in the House and 62.5 in the Senate.

70. A total of seventy-eight separate industry groups (trade associations and labor unions) appeared before the committee; only forty-eight testified on the Fordney-McCumber bill in 1922, and in previous years the numbers were even lower- thirty testified in 1913, and only twenty-one testified in 1909. The Smoot-Hawley tariff remains somewhat enigmatic. On one hand, Schattschneider's classic analysis places these groups at center stage. Schattschneider 1935. On the other hand, the act was still very much a partisan piece of legislation sponsored by Republicans and opposed by Democrats. See Pastor 1980, 81; and Verdier 1994, 191-92.

71. He supported the plank in the platform, co-authored by Cordell Hull, that returned the party to Wilson's idea of a "competitive tariff" and advocated reciprocal trade treaties. But in the campaign he supported a cost-equalizing approach that he admitted was "not widely different from that preached by Republican statesmen and politicians." Quoted in Haggard 1988, 106.

72. See Haggard 1988, 92; and Verdier 1994, 188. Neither the AFL nor the CIO took a position on the RTAA or its extension in 1937. 
In 1948 the Republicans altered their platform, too, removing their old pledge to end the RTAA program. And in 1953 Eisenhower championed trade liberalization as an essential component of postwar U.S. foreign policy. The party's support base among business was split between export-oriented sectors and those industries that began to meet stiff import competition in the 1950s and 1960s, such as textiles and steel. ${ }^{73}$ The Democrats faced their own problems. The AFL-CIO voiced lukewarm support for the RTAA program during the postwar boom but withdrew it when cheap imports began to pose a serious threat to wages and jobs in several major industries. ${ }^{74}$ The Democrats' rural support base divided along commodity lines over trade. ${ }^{75}$ Growing pressure from industry groups exacerbated the problem for party leaders and resulted in a spate of special legislation in Congress and a new array of nontariff barriers aimed at protecting faltering industries. ${ }^{76}$ By the 1990 s, the old class coalitions were in disarray over the trade issue, and the two parties were rent by internal divisions over major trade legislation. ${ }^{77}$

\section{Britain}

Levels of factor mobility were far higher in Britain than elsewhere in the early part of the nineteenth century. According to the theory, the development of class coalitions should have occurred earlier in Britain and should have been replaced by industry coalitions during the mid- to late twentieth century when levels of mobility declined rapidly. These expectations, and a summary of the findings, are presented in Table 3.

With the revival of trade after the Napoleonic Wars, debates in Britain centered on the protectionist Corn Laws that restricted grain imports and were defended resolutely by the land-owning elite ${ }^{78}$ Pressure for reform came most strongly from textile producers in Leicester and Manchester, anxious to reduce labor costs. ${ }^{79} \mathrm{But}$ in the 1830s the Anti-Corn Law League drew a mass following among both the urban middle and working classes and attracted support from the working-class Chartist reform movement. ${ }^{80}$ The effects were quickly apparent in Parliament where

73. The two general business associations, the NAM and the Chamber of Commerce, provided only cautious support for multilateral trade negotiations and, constrained by internal conflicts of interests, took few positions on more controversial trade issues. See Friman 1990, 65-66; and Bauer, Pool, and Dexter $1963,334-36$.

74. See Rogowski 1989, 120; and Hughes 1979, 23.

75. The American Farm Bureau took positions on some broad trade measures, generally supporting GATT negotiations-from which agricultural trade barriers had been excluded-while opposing preferences for imports from developing nations. But it left the most important lobbying up to commodityspecific farm groups. Destler and Odell 1987, 42.

76. On the rise of lobbying, both for and against trade liberalization, see Destler and Odell 1987. When major trade bills came before the House committee, forty-two industry groups testified in 1955 , sixty-three testified in 1962, fifty-six in 1974, thirty-nine in 1993, and fifty-four in 1994.

77. Turner and Schneier 1970, 71. Average party cohesion indexes for votes on trade bills in the House were 43.9 (1955), 43.3 (1962), 36.3 (1974), 33.0 (1993), and 33.0 (1994).

78. Toynbee [1884] 1958, 5 .

79. McCord 1958, 16.

80. Magnus 1954, 65-66. 
TABLE 3. Anticipated and observed outcomes in Britain

\begin{tabular}{|c|c|c|c|c|c|}
\hline Period & $\begin{array}{c}\text { Factor } \\
\text { endowments }\end{array}$ & Mobility & Prediction $^{\mathbf{a}}$ & $\begin{array}{l}\text { Outcomes: Class- } \\
\text { based parties and } \\
\text { associations }\end{array}$ & Industry groups \\
\hline $1815-69$ & $\begin{array}{l}\text { Abundant labor } \\
\text { and capital; } \\
\text { scarce land }\end{array}$ & High & $\begin{array}{l}\text { Class } \\
\text { coalitions }\end{array}$ & $\begin{array}{l}\text { Liberals strongly } \\
\text { supported free } \\
\text { trade; Tories } \\
\text { protectionist, but } \\
\text { split by Peelite } \\
\text { faction in } 1846\end{array}$ & $\begin{array}{l}\text { Little independent } \\
\text { activity; } \\
\text { combined in Anti- } \\
\text { Corn Law League }\end{array}$ \\
\hline $1870-1914$ & $\begin{array}{l}\text { Abundant labor } \\
\text { and capital; } \\
\text { scarce land }\end{array}$ & High & $\begin{array}{l}\text { Class } \\
\text { coalitions }\end{array}$ & $\begin{array}{l}\text { Liberals and } \\
\text { Labour gave } \\
\text { strong, unified } \\
\text { support for free } \\
\text { trade; Tory leaders } \\
\text { censored } \\
\text { protectionist } \\
\text { members }\end{array}$ & $\begin{array}{l}\text { Few groups gave } \\
\text { testimony to } \\
\text { commissions }\end{array}$ \\
\hline $1919-39$ & $\begin{array}{l}\text { Abundant labor } \\
\text { and capital; } \\
\text { scarce land }\end{array}$ & $\begin{array}{l}\text { Intermediate; } \\
\text { falling }\end{array}$ & Mixed & $\begin{array}{l}\text { Tories advocated } \\
\text { tariffs under } \\
\text { Baldwin but were } \\
\text { divided; Labour } \\
\text { and TUC } \\
\text { supported free } \\
\text { trade until } \\
\text { Depression }\end{array}$ & $\begin{array}{l}\text { Activity increased } \\
\text { after onset of } \\
\text { Depression }\end{array}$ \\
\hline $1945-94$ & $\begin{array}{l}\text { Abundant labor } \\
\text { and capital; } \\
\text { scarce land }\end{array}$ & Low & $\begin{array}{l}\text { Industry } \\
\text { coalitions }\end{array}$ & $\begin{array}{l}\text { Tories and Labour } \\
\text { split in votes over } \\
\text { entrance to EC } \\
\text { and GATT rounds; } \\
\text { CBI and TUC also } \\
\text { internally divided }\end{array}$ & $\begin{array}{l}\text { Very active in } \\
\text { pressuring } \\
\text { planning agencies } \\
\text { for assistance }\end{array}$ \\
\hline
\end{tabular}

${ }^{a}$ Class coalitions are expected to imply that class-based organizations are internally unified on trade and adopt coherent platforms while groups are inactive. Industry coalitions imply that class-based organizations are internally divided on trade and adopt ambiguous positions (see Table 1).

bUsing 1966 data, Bowen, Leamer, and Sveikauskas (1987) find Britain to be very abundant in all categories of labor (except agricultural workers), and very scarce in all types of land. In contrast to Rogowski's findings, however, they find Britain to be relatively scarce in capital.

Liberals and Radicals backed the league wholeheartedly and Tories voted strongly against liberalizing bills. ${ }^{81}$ When Peel pushed ahead with repeal of the Corn Laws in 1846 after a series of food crises, he split the Tories irrevocably; the expelled 
Peelite faction (which included the young Gladstone) gravitated to the Liberal fold. ${ }^{82}$ With the "purified" Tories increasingly isolated on the trade issue, Liberals succeeded in eliminating all protectionist duties by 1860 .

In 1867 the second Reform Act nearly doubled the size of the electorate and, by enfranchising more members of the urban working and middle classes, created a massive base of support for free trade ${ }^{83}$ By tying their party to the free-trade cause, Gladstone's Liberals forged a huge electoral support base. The Tories could not ignore demands from rural supporters for protection, but to openly endorse tariffs would have been electoral suicide. ${ }^{84}$ They began to draw more support from the expanding Victorian middle class, which grew defensive on labor and social issues but favored trade openness. ${ }^{85}$ Tory leaders responded by cultivating an ambiguous position on the tariff issue. ${ }^{86}$ The party came under little pressure from industry lobbies ${ }^{87}$ but it could not ignore the old divisions within the ranks indefinitely. In 1903 twenty-seven Unionist backbenchers challenged the party leadership on the trade issue by supporting Baldwin's Tariff Reform program ${ }^{88}$ The bickering helped ensure the continued Liberal dominance in Parliament and guaranteed that British trade policy remained steadfastly open well into the twentieth century.

After the dissolution of the wartime coalition under David Lloyd George in 1922, the tariff became grist for open partisan competition, pitting the Liberal-Labour alliance against the Conservatives. In 1923 Baldwin made the Tories' commitment to protection the focus of the campaign and so virtually handed victory to MacDonald. ${ }^{89}$ In 1929 he repeated the mistake. But the onset of a depression discredited MacDonald's policies and broke apart the Liberal-Labour alliance. Business and middle-class support swung behind the Tories, who were swept into office in 1931

on all other votes in the corresponding sessions of Parliament: 67.9 (1834), 58.4 (1842), and 58.4 (1846).

82. Bradford 1983, 159. Tory supporters had been divided between those whose interests were bound up exclusively in agriculture and those who had diversified by investing in manufacturing and railways. See Schonhardt-Bailey 1991; and Aydelotte 1962, 290-307. Peel himself had interests in cotton spinning, and Leaguers noted wryly that he had "commercial blood in him."

83. Cox 1987, 10.

84. As Lord Derby put it at the time, the working class "can, if it chooses, outvote all other classes put together." Quoted in McKenzie 1963, 147.

85. Ostrogorski 1902, 267-68.

86. Zebel 1940, 173. Party leaders censured backbenchers from speaking out on the issue and avoided any discussion of a change in policy. Brown 1943, 65. They had an added incentive for shelving the trade issue after 1886 when they were joined by a faction of the Liberal party, the Liberal Unionists, who had split with Gladstone on Irish home-rule and held strong pro-trade views. Lubenow 1988. Votes in Parliament, limited to proposals for minor policy adjustments, produced cohesion indexes of 91.1 (1881), 94.6 (1894), 95.2 (1897), and 92.6 (1906).

87. Verdier 1994, 84-88. Only eleven trade associations responded to inquiries from a Royal Commission on trade and industry in 1886 , and four of these expressed no particular opinion. Ibid., $87-88$.

88. The drive behind Tariff Reform came not from industry demands or agrarian dissent, but from growing concerns about imperial ties and the need for preferential trade policy. See Verdier 1994, 140; also Marrison's (1983) response to Semmel (1960) and Rempel (1972).

89. Lowe $1942,82-83$. 
and raised tariffs in 1932. Divisions over the trade issue grew within the parties. ${ }^{90}$ Among business interests, the old consensus dissolved and industries began more concerted lobbying efforts aimed at securing protection. ${ }^{91}$ On the Left, where there had been little dissent from the Trade Union Council's support for free trade, ${ }^{92}$ after 1930 key unions in the woolens and iron and steel industries began demanding special protection. ${ }^{93}$

By the 1960s, the Tories and Labour had both committed themselves to a program of planning that included subsidies targeted to major trade-affected industries as a counterweight to GATT-mandated tariff reductions. ${ }^{94}$ The approach helped to paper over deep rifts in each party's core class constituency, while responding to lobbying pressure from individual industries. ${ }^{95}$ A growing division separated Labour moderates from the "Bevanite" Left wing of the party that, linked to powerful unions in the mining, steel, and textile industries, supported unilateral tariff increases in violation of GATT and vehemently opposed British entry into the European Community. ${ }^{96}$ The Trade Union Council itself was deeply divided along industry lines and vacillated on trade issues. ${ }^{97}$ Meanwhile, on the Right, tensions also grew among the Tories. When the Heath government reacted to the recession in the early $1970 \mathrm{~s}$ by providing selective protection for major industries, ${ }^{98}$ it drew intense criticism (especially from small business) at party conferences. ${ }^{99}$ In the $1980 \mathrm{~s}$ divisions among Tories over European integration widened further as the Right wing of the party became increasingly vocal in its opposition.

\section{France}

The theory suggests a very different history for trade cleavages in France, where levels of factor mobility have been much lower than elsewhere during the last two centuries. Industry-based cleavages over trade were more likely than class conflict for most of the period considered here. The likelihood of a strengthening of class

90. Average cohesion indexes in voting on trade legislation fell to 66.3 (1921), 58.0 (1924), and 67.8 1932).

91. See Turner 1984, 48; and Verdier 1994, 176. The Federation of British Industry came out in favor of tariffs.

92. See Carr and Taplin 1962, 341; and Boyce 1987, 124-25.

93. Verdier $1994,174$.

94. See Blank 1973; and Verdier 1994, 265.

95. Indeed, trade associations and labor unions from major industries were granted special access to planning agencies. See Hall 1986, 56; Grant 1980; Shonfield 1965, 151-52; and Hayward 1974, 401. This was a major feature of what Beer labeled the "new group politics" in Britain. Beer 1965.

96. Wilson applied for EC entry in 1967 but opposed the same move by the Heath government in 1971 after the Left wing gained strength (see Nairn 1972). In the end he resolved the matter for the party by holding a referendum on the issue in 1974. When the Left succeeded in radicalizing the party platform again in the $1980 \mathrm{~s}$, however, it reinserted a pledge to withdraw from the EC and impose import barriers. King 1977. In the one vote on EC entry in Parliament in 1971, the cohesion index for Labour was only 46.5 ( 69 for, 189 against). The cohesion index for the Tories was 75.7 ( 282 for, 39 against).

97. See Rose 1980, 233; and Hall 1986, 60.

98. See Ganz 1977, 40; and Young and Lowe 1974.

99. See Gamble and Walkland 1984, 78-81; and Grant 1980. 
TABLE 4. Anticipated and observed outcomes in France

\begin{tabular}{|c|c|c|c|c|c|}
\hline Period & $\begin{array}{c}\text { Factor } \\
\text { endowments }\end{array}$ & Mobility & Prediction $^{\mathrm{a}}$ & $\begin{array}{l}\text { Outcomes: Class- } \\
\text { based parties and } \\
\text { associations }\end{array}$ & Industry groups \\
\hline $1815-69$ & $\begin{array}{l}\text { Abundant labor } \\
\text { and capital; } \\
\text { scarce land }\end{array}$ & Low & $\begin{array}{l}\text { Industry } \\
\text { coalitions }\end{array}$ & - & $\begin{array}{l}\text { High activity; } \\
\text { great number of } \\
\text { petitions from } \\
\text { groups to } \\
\text { Assembly }\end{array}$ \\
\hline $1870-1914$ & $\begin{array}{l}\text { Abundant labor } \\
\text { and capital; } \\
\text { scarce land }\end{array}$ & Low & $\begin{array}{l}\text { Industry } \\
\text { coalitions }\end{array}$ & $\begin{array}{l}\text { Republicans, } \\
\text { Bonapartists, } \\
\text { monarchists, and } \\
\text { Radicals divided; } \\
\text { Socialists supported } \\
\text { free trade }\end{array}$ & $\begin{array}{l}\text { High activity; } \\
\text { industry lobbies } \\
\text { mounted major } \\
\text { efforts to alter } \\
\text { outcomes of } \\
\text { Chamber } \\
\text { hearings on tariff }\end{array}$ \\
\hline 1919-39 & $\begin{array}{l}\text { Abundant labor } \\
\text { and capital; } \\
\text { scarce land }\end{array}$ & Intermediate & Mixed & $\begin{array}{l}\text { Increase in } \\
\text { partisanship; } \\
\text { Socialists favored } \\
\text { reform, Radicals } \\
\text { opposed and ended } \\
\text { Front Populaire }\end{array}$ & $\begin{array}{l}\text { Group lobbies } \\
\text { active in } \\
\text { pressuring } \\
\text { committees for } \\
\text { tariff alterations } \\
\text { and in treaty } \\
\text { bargaining }\end{array}$ \\
\hline $1945-94$ & $\begin{array}{l}\text { Abundant labor } \\
\text { and capital; } \\
\text { scarce land }^{\mathrm{b}}\end{array}$ & Low & $\begin{array}{l}\text { Industry } \\
\text { coalitions }\end{array}$ & $\begin{array}{l}\text { Gaullists and } \\
\text { Socialists divided } \\
\text { over trade and EC, } \\
\text { as were FNSEA and } \\
\text { CNPF (Conseil } \\
\text { national du patronat } \\
\text { français); CGT more } \\
\text { protectionist than } \\
\text { CFDT }\end{array}$ & $\begin{array}{l}\text { Planning process } \\
\text { dominated by } \\
\text { intense industry } \\
\text { lobbying }\end{array}$ \\
\hline
\end{tabular}

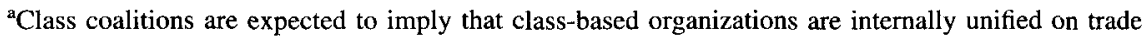
and adopt coherent platforms while groups are inactive. Industry coalitions imply that class-based organizations are internally divided on trade and adopt ambiguous positions (see Table 1).

bUsing 1966 data, Bowen, Leamer, and Sveikauskas (1987) find France to be abundant in all types of labor (though least abundant in agricultural workers) and scarce in arable land. In contrast to Rogowski's findings, they find France to be relatively scarce in capital.

coalitions may have risen marginally in the $1920 \mathrm{~s}$ and $1930 \mathrm{~s}$, with a slight increase in measured levels of mobility. For the most part, however, the French economy stands apart from the others as especially fertile ground for the formation of narrow industry-based coalitions. Table 4 summarizes the anticipated effects and findings. 
The absence of democratic institutions and party competition in the turbulent years after 1815 makes testing of the theory against French politics difficult in the first part of the nineteenth century. However, no matter how the political institutions changed in these years, active lobbying by industry groups appears to have been a constant feature. Under Louis XVIII, grain interests won higher tariffs even as an array of agrarian producers (led by wine makers and silk growers) pushed for freer trade. ${ }^{100}$ Under the July Monarchy, industries flooded the Assembly with petitions and sent leaders to represent them in Paris. ${ }^{101}$ An 1834 national survey on trade found that many chambers of commerce held very protectionist views (including those representing cotton weavers and iron producers), but in commercial circles and export industries (such as fine fabrics and metal goods) freer trade was firmly supported. ${ }^{102}$ The wine makers of Bordeaux took the initiative in forming a freetrade association in 1846, in the wake of the dramatic reform in Britain. But, unlike the Anti-Corn Law League, it never mobilized a class base of support. ${ }^{103}$ Only under the authoritarian rule of Louis Napoleon was trade policy reformed by a series of bilateral trade treaties in the 1860 s. ${ }^{104}$

After the collapse of the Second Empire, a complex multiparty system began to take shape in the 1870s. By 1872 there were eight major parties contesting elections. On the tariff issue, positions were poorly delineated and the parties were internally split in votes in the Chamber of Deputies. ${ }^{105}$ On the Right, most Bonapartists remained loyal to the emperor's pro-trade legacy, while monarchists of various stripes tended to favor agricultural tariffs or were divided according to how trade affected different landed interests. On the Left, Socialists tended to support freer trade, but Radicals were less clearly positioned. ${ }^{106}$ The Republicans, who emerged as the dominant centrists in Parliament with strong support among urban business interests and the middle class, were especially divided. The divisions deepened when the trade treaties with Britain and Belgium came up for renewal in 1878 . When the Chamber began hearings on the issue, it was swamped by lobbyists. ${ }^{107}$ By

100. See Caron 1979, 95-97; and Brogan 1967, 405.

101. See Gille 1968, 209-49; and Verdier 1994, 98. In 1840 iron masters organized into a national committee to lobby against trade liberalization. Coal miners organized a committee in 1851 to demand protection from imports of British coal. Priouret 1963, 69-71. Machine builders also organized their own committee, but they lobbied for freer trade.

102. See Caron 1979, 96; and Smith 1980, 90.

103. Russell 1969, 97-98. Keenly aware of the very different political context in France, Cobden had advised his friend Bastiat that "the free trade movement, which was formed on a broad base in England and forced upon the legislature, must in France start with the legislators and be imposed on the people." Quoted in Russell 1969, 84.

104. Dunham 1930. Even then, the government was forced to adopt a range of measures aiding particular interests harmed by the treaties, including a program that subsidized land owners and provided loans to industry. See Fohlen 1956, 293; and Dunham 1930, 150.

105. See Gourevitch 1986, 104; and Elwitt 1975, 270-72. Average party cohesion indexes on trade votes were 24.5 (1872), 29.7 (1878), and 47.1 (1892).

106. Verdier 1994, 101.

107. For a detailed account, see Smith 1980. Protectionist industries lobbied independently and also combined forces in the Association de l'industrie française (AIF). The largest contingent in the AIF came 
1892, when the treaties expired again, protracted agricultural recession had pushed farmers, and the agrarian peak association, the Sociéte des agriculteurs de France (SAF), toward protectionism. ${ }^{108}$ The Méline government avoided a repeat of 1878 with a compromise that assured major industries duty-free imports of key raw materials while providing new assistance for a range of agricultural producers and manufacturers. ${ }^{109}$ The compromise removed the trade issue from the political spotlight and helped the Republicans dominate the French Parliament until World War I. ${ }^{110}$

In the years after 1919 Parliament extended wartime legislation authorizing the government to adjust tariffs in line with exchange-rate changes, and industry groups were able to wield enormous influence over the advisory committees in charge of setting tariff rates. ${ }^{111}$ The governing Republicans and Radicals sought to maintain the balance between competing interests that had been cemented in the Méline Tariff. Representatives of labor, however, began expressing a more coherent form of class sentiment: the Socialists and Communists, along with the union peak association, the Confédération générale du travail (CGT), all favored greater openness. ${ }^{112}$ It took a sharp decline in commodity prices in 1930 to break the Republican grip on power. The Steeg government collapsed in 1931, paralyzed by its unwillingness to choose between urban and rural interests. The new Radical government imposed import quotas on a range of farm products but could not avert economic crisis. In 1936 the Radicals joined with Socialists (under Blum) and Communists in a novel "red-green" coalition, the Front Populaire. ${ }^{113}$ The new alignment, ostensibly pitting farmers and workers against business, was plagued by conflicts and short-lived. Fearing that Blum planned to use emergency powers to cut agricultural protection in 1937, the Radicals deserted the alliance. The new Radical government restored old duties and quotas and courted support from Republicans and business interests. ${ }^{114}$

\footnotetext{
from textile manufacturers; iron and steel producers and the coal-mining industry were also prominent participants. Support for free trade emanated predominantly from the major centers of trade, finance, and transport. Major sections of industry joined them, including the woolens and silk industries and the wine producers, and helped to form a free-trade association (the Association pour la défense de la liberté commerciale) as a counter-weight to the AIF. Some seventy-three separate industry groups offered testimony.

108. Golob 1944, 43.

109. See Verdier 1994, 126; and Smith 1980, 151-81.

110. As Smith points out, the 1892 tariff, "served to mitigate strife amongst capitalists in different lines or in different sectors by producing an explicit government commitment to a mixed, variegated, and balanced economy in which all major interests could enjoy a certain level of security." Smith 1980, 21.

111. Verdier 1994, 164. In fact, between 1919 and 1922 the calculation of duty multipliers was handled by a committee staffed largely by representatives of trade associations. Naudin 1928, 89-91.

112. Verdier 1994, 162.

113. See Wright 1964, 64; and Dupeux 1959.

114. Sauvy 1984, 151. In the vote on granting the Chautemps government power to adjust tariffs in 1937, the average party cohesion index was 84.9 . Socialists and Communists voted unanimously against the bill, whereas Republicans were split.
} 
Under the continued dominance of the Right and Center-Right, trade politics in the 1950s and 1960s developed little partisan flavor. The creation of the European Economic Community in 1958 placed limits on discretionary changes in the tariff and shifted the focus to industrial policy. The famous planning process was powerfully shaped by industry groups, as bureaucratic agencies began to act as internal lobbyists for their sectoral "clients". ${ }^{115}$ As in Britain, there was a clear split between the large, concentrated industries, which tended to do very well in lobbying for rents, and small business, which did not. ${ }^{116}$ Among farmers, opinions about policy were divided: the peak association, the Fédération nationale des syndicats des exploitants agricoles (FNSEA), comprised around forty specialized farmer groups that took very different positions on trade. ${ }^{117}$ In Parliament, Gaullist and Republican party members were divided over trade and industrial policy in the 1970s and 1980s. ${ }^{118}$ Among Socialists, there was strong support for European integration and liberalization from leading figures of the "second Left", while Left wingers associated more closely with blue-collar unions and the CGT championed protection. ${ }^{119}$ In government the parties gravitated toward similar, amorphous approaches to policy: negotiated tariff cuts were coupled with large servings of nontariff protection and an array of selective state intervention aimed at aiding troubled and "strategic" industries.

\section{Sweden}

The theory predicts an altogether different pattern of development in Sweden, where levels of factor mobility rose dramatically at the turn of the century and remained quite high in later decades. We anticipate a rapid reshaping of trade politics around class cleavages late in the nineteenth century. And, since mobility levels remained relatively high in the twentieth century, the formation of narrower, industry-based coalitions in later periods was unlikely. Expectations and findings are reported in Table 5.

Since we have little data on wages and profits for Sweden in the first half of the nineteenth century, it is difficult to make clear predictions. Testing the theory is also difficult given the absence of democratic institutions and parties. The Riksdag did allow for representation of interests in this period, however, and it seems that the

115. Hall 1986. Indeed, in the 1960 s and 1970 s many trade associations actually merged with the government agencies created to supervise them. Mytelka 1982. By the 1970s, trade associations in the footwear, watch, clock, and television industries were formulating the plans for those industries and even negotiated directly with foreign producers and governments to establish voluntary restraints on imports. Milner 1988, 198.

116. Hall 1986, 169-70.

117. Safran $1985,107-18$.

118. Gourevitch $1986,186$.

119. Mitterrand eventually affirmed his support for European integration in the early $1980 \mathrm{~s}$, even though several Socialist ministers opposed it, and the Communists called for French withdrawal from the $\mathrm{EC}$ altogether. 
TABLE 5. Anticipated and observed outcomes in Sweden

\begin{tabular}{|c|c|c|c|c|c|}
\hline Period & $\begin{array}{c}\text { Factor } \\
\text { endowments }\end{array}$ & Mobility & Prediction $^{\mathrm{a}}$ & $\begin{array}{l}\text { Outcomes: Class- } \\
\text { based parties and } \\
\text { associations }\end{array}$ & Industry groups \\
\hline $1815-69$ & $\begin{array}{l}\text { Abundant labor; } \\
\text { scarce land and } \\
\text { capital }\end{array}$ & Intermediate? & Mixed? & - & $\begin{array}{l}\text { Evidence of some } \\
\text { group pressures on } \\
\text { Riksdag; craft } \\
\text { guilds opposed } \\
\text { liberal reforms }\end{array}$ \\
\hline $1870-1914$ & $\begin{array}{l}\text { Abundant labor; } \\
\text { scarce land and } \\
\text { capital }\end{array}$ & High & $\begin{array}{l}\text { Class } \\
\text { coalitions }\end{array}$ & $\begin{array}{l}\text { Ruralists and } \\
\text { Conservatives } \\
\text { supported } \\
\text { protection; Social } \\
\text { Democrats } \\
\text { championed free } \\
\text { trade }\end{array}$ & $\begin{array}{l}\text { Few groups } \\
\text { actively lobbied } \\
\text { on trade }\end{array}$ \\
\hline $1919-39$ & $\begin{array}{l}\text { Abundant } \\
\text { capital; scarce } \\
\text { labor and land } \\
\text { b }\end{array}$ & High & $\begin{array}{l}\text { Class } \\
\text { coalitions }\end{array}$ & $\begin{array}{l}\text { Parties adhered to } \\
\text { old platforms, LO } \\
\text { and SAF } \\
\text { supported free } \\
\text { trade; "cow } \\
\text { trade" between } \\
\text { Social Democrats } \\
\text { and Agrarians }\end{array}$ & $\begin{array}{l}\text { Accommodation } \\
\text { between parties and } \\
\text { peak associations } \\
\text { left little room for } \\
\text { lobbying }\end{array}$ \\
\hline $1945-94$ & $\begin{array}{l}\text { Abundant labor } \\
\text { and capital; } \\
\text { scarce land }^{\mathrm{c}}\end{array}$ & High & $\begin{array}{l}\text { Class } \\
\text { coalitions }\end{array}$ & $\begin{array}{l}\text { Dominant Social } \\
\text { Democrats, } \\
\text { opposition } \\
\text { parties, and peak } \\
\text { associations all } \\
\text { held to free-trade } \\
\text { consensus }\end{array}$ & $\begin{array}{l}\text { Little activity; more } \\
\text { lobbying in } 1980 \text { s }\end{array}$ \\
\hline
\end{tabular}

${ }^{a}$ Class coalitions are expected to imply that class-based organizations are internally unified on trade and adopt coherent platforms while groups are inactive. Industry coalitions imply that class-based organizations are internally divided on trade and adopt ambiguous positions (see Table 1).

'Here Rogowski's classification is problematic. He argues that the evidence on factor endowments indicating labor abundance belies an effective scarcity due to "familial self-exploitation" within the peasant population. The evidence alone (which is consistent with later data) would actually lead us to predict that workers (and the organizations representing them) would support free trade, not protection, as the analysis here seems to bear out.

'Using 1966 data, Bowen, Leamer, and Sveikauskas (1987) find Sweden to be abundant in capital and all types of labor (except agricultural workers) and scarce in arable land.

greatest support for the liberalizing reforms begun by Oscar I in the 1840s came from a mix of specific agricultural and business interests. In particular, timber and lumber interests, producers of iron ore and pig iron, and the commercial centers all 
were strong supporters of reform and especially elimination of the protectionist Produktplakat. ${ }^{120}$ Grain, meat, and dairy producers, and burghers in the tightly regulated textile and iron industries, were vocal opponents. ${ }^{121}$ Oscar's most radical reforms, establishing free trade in agricultural goods, were implemented by Gripenstedt in the 1850s and 1860s and helped to weaken support for the old regime. In 1866 the Riksdag was transformed into a bicameral parliament with elected representatives, and organized political parties began to form.

In the 1870s the lingering depression generated new protectionist demands among a large section of the agricultural population, especially in the grain-growing regions of Svealand and northern Götaland. The Liberal Themptander government, backed strongly by urban voters and business interests, negotiated a new liberal treaty with France in 1882, and the political conflict over trade quickly escalated. A protectionist league, and a rival Association Against a Tariff on Foodstuffs, formed, and in 1887 two elections to the lower chamber of the Riksdag were fought on the tariff issue. ${ }^{122}$ Boström's new Ruralist government imposed high tariffs on agricultural products, and when the French treaty expired in 1892 , raised tariffs again. ${ }^{123}$ Opposition came not only from the Liberals but also from the Social Democratic clubs and trade unions representing the still-disenfranchised working class. In 1889 these elements founded the Social Democratic party, which took a firm stand against protection and turned the deepening class cleavage into a clear partisan battle. ${ }^{124}$ When a coalition of the Social Democrats and Liberals finally won control of government in 1917-in the wake of electoral reform - they immediately liberalized Swedish trade policy.

The alliance between Social Democrats and Liberals broke apart in 1920 over the issue of tax reform and was followed by a string of short-lived minority governments. In 1929 and 1930, with a farm crisis growing, the coalition government of Conservatives and Agrarians attempted to pass new protectionist legislation but was defeated by strong opposition from Social Democrats and urban Liberals. In 1932, in the midst of the depression, the Social Democrats formed a new minority government, this time with support from the Agrarians. They outlined a program to combat unemployment and relieve agricultural distress, and passed tariff-cutting legislation with the support of both Agrarians and Liberals. The 1936 election gave the Social Democrats a majority in the lower chamber, but they were assiduous in tending to the "cow trade" and allowed a range of specific tariffs and

120. See Rustow 1955, 24; and Heckscher 1954, 218, 224-25. The Produktplakat prohibited any foreign vessel from importing to Sweden any goods other than those produced in its home country and raised duties by $40-50$ percent for imports and exports carried on foreign ships.

121. See Montgomery 1939, 114; and Heckscher 1954, 233.

122. Rustow 1955,34 . In the first election free traders won a majority; in the second they were robbed of victory by an electioneering blunder (in Stockholm, a stronghold of free-trade sentiment, protectionists discovered an irregularity in the tax records of one of the candidates and succeeded in having all the free-trade representatives disqualified). Rustow 1955, 36.

123. Verney 1957, 108-109.

124. Rustow $1955,42$. 
subsidies to aid farmers. ${ }^{125}$ In 1938 , in an effort to be included in the bargaining, business associations met with labor and farming organizations and concluded the famous Pact of Saltsjöbaden. The broad accommodation between class interestssuccessful where the French Popular Front had failed-included a commitment to liberal trade policy and left little room for industry groups in the policymaking process.

In the years after 1945 the dominant Social Democrats and the Conservative parties all backed a liberal approach to trade policy that emphasized the need for smooth adjustment to the demands of the international market, aided by vigorous retraining and adjustment assistance policies. ${ }^{126}$ The parties and peak associations, including the Landsorganisationen and the Svenska Arbetsgivarforeningen, remained unified internally on the trade issue, and on economic issues in general, and group lobbying was severely limited. ${ }^{127}$ To a large degree the Social Democrats' policy of wage equalization took the trade issue out of politics, since it meant that the differential effects of trade on wages in particular sectors were minimized. This level of "solidarity" was made feasible by extensive mobility-enhancing policiesthe hallmark of Swedish policy in the postwar period. ${ }^{128}$ When the Social Democrats finally lost power in 1976, the new Center-Right government maintained its commitment to open markets and continued to support adjustment assistance and retraining programs. Only in the 1980s were there signs of change when the Landsorganisationen and Svenska Arbetsgivarforeningen began to face growing challenges by member groups. ${ }^{129}$

\section{Canada and Australia}

In Canada, levels of inter-industry mobility have remained relatively low throughout most of the period considered here. ${ }^{130}$ According to the theory, we thus expect

125. Sainsbury 1980, 33. The 1936 party manifesto assured the Agrarians that "the Swedish working class will pay the price necessary to guarantee workers in agriculture and small farmers a tolerable living standard." Mabbett 1995, 87. Rogowski has attempted to explain the alliance by reference only to trade politics, suggesting that labor in Sweden might be considered a scarce factor at this time (due to "familial self-exploitation" among the peasantry) like land, and so was aligned with farmers in favor of protection. Rogowski 1989, 84-86. The problem with this interpretation is that Swedish labor and the Social Democrats continued to support open trade and only made specific concessions to farmers in order to preserve the alliance.

126. See Jones 1976, 22-25; and Katzenstein 1985, 65.

127. Sjoblom 1985, 24-25, 51.

128. Jones 1976, 39-42. The seminal plan was devised in 1951 by economists Gösta Rehn and Rudolf Meidner. Heclo and Madsen 1987, 49-50. After initial hesitation, even the protectionist-leaning textile workers agreed to retraining and relocation benefits as an alternative to preserving jobs in their declining industry. Milner 1989, 109. This, according to Rehn, was exactly the plan's objective: "to avoid protective and protectionist palliatives when changes in the world trade situation or other trade conditions create difficulties for various groups." Rehn 1985, 1.

129. Weaver 1987, 305. Labor unions in the export-oriented engineering industries grew increasingly discontent with centralized wage bargaining. Similarly, SAF members pushed harder for more freedom to bargain with their workers independently with respect to wages (see Pontusson and Swenson 1993).

130. For a more detailed discussion of these cases, see Hiscox 1997 and forthcoming. 
TABLE 6. Anticipated and observed outcomes in Canada

\begin{tabular}{|c|c|c|c|c|c|}
\hline Period & $\begin{array}{c}\text { Factor } \\
\text { endowments }\end{array}$ & Mobility & Prediction $^{\mathbf{a}}$ & $\begin{array}{l}\text { Outcomes: Class- } \\
\text { based parties and } \\
\text { associations }\end{array}$ & Industry groups \\
\hline $1815-69$ & $\begin{array}{l}\text { Abundant land; } \\
\text { scarce capital } \\
\text { and labor }\end{array}$ & Low & $\begin{array}{l}\text { Industry } \\
\text { coalitions }\end{array}$ & $\begin{array}{l}\text { Tories favored high } \\
\text { tariff and Liberals } \\
\text { opposed, but both } \\
\text { split along regional } \\
\text { lines }\end{array}$ & $\begin{array}{l}\text { Highly active; } \\
\text { many groups } \\
\text { petitioned the } \\
\text { Assembiy }\end{array}$ \\
\hline $1870-1914$ & $\begin{array}{l}\text { Abundant land; } \\
\text { scarce capital } \\
\text { and labor }\end{array}$ & Low & $\begin{array}{l}\text { Industry } \\
\text { coalitions }\end{array}$ & $\begin{array}{l}\text { Liberals very } \\
\text { divided; Tories more } \\
\text { united on } \\
\text { protectionist } \\
\text { National Policy }\end{array}$ & $\begin{array}{l}\text { Highly active; } \\
\text { groups petitioned } \\
\text { House and } \\
\text { lobbied } \\
\text { Dominion Board } \\
\text { of Trade }\end{array}$ \\
\hline 1919-39 & $\begin{array}{l}\text { Abundant land } \\
\text { and capital; } \\
\text { scarce labor }\end{array}$ & $\begin{array}{l}\text { Intermediate; } \\
\text { rising }\end{array}$ & Mixed & $\begin{array}{l}\text { Liberals and Tories } \\
\text { supported National } \\
\text { Policy, but split by } \\
\text { western agrarian } \\
\text { movement }\end{array}$ & $\begin{array}{l}\text { Little evidence } \\
\text { of group } \\
\text { lobbying }\end{array}$ \\
\hline $1945-94$ & $\begin{array}{l}\text { Abundant land } \\
\text { and capital; } \\
\text { scarce labor }^{\mathbf{b}}\end{array}$ & Low & $\begin{array}{l}\text { Industry } \\
\text { coalitions }\end{array}$ & $\begin{array}{l}\text { Both major parties } \\
\text { supported GATT } \\
\text { process, but divided } \\
\text { over CUSFTA and } \\
\text { NAFTA }\end{array}$ & $\begin{array}{l}\text { Groups active in } \\
\text { pushing for } \\
\text { special deals }\end{array}$ \\
\hline
\end{tabular}

${ }^{a}$ Class coalitions are expected to imply that class-based organizations are internally unified on trade and adopt coherent platforms while groups are inactive. Industry coalitions imply that class-based organizations are internally divided on trade and adopt ambiguous positions (see Table 1).

${ }^{b}$ Using 1966 data, Bowen, Leamer, and Sveikauskas (1987) find Canada to be abundant in capital and all types of land and scarce in all types of labor except agricultural workers.

strong industry cleavages in Canadian trade politics, with perhaps the only change coming in the interwar years when the wages data indicate that mobility rose to "intermediate" levels. The evidence, summarized in Table 6, fits reasonably well with these expectations.

Dominated by MacDonald's Tories in the early nineteenth century, trade politics in Canada was strongly shaped by patronage and group pressures. ${ }^{131}$ The chief supporters of free trade were grain growers and timber producers in the western provinces, whereas farmers in the eastern provinces as well as the 
iron and textile industries lobbied for protection. Industry and regional divisions cut across factor classes. ${ }^{132}$ The tariff became more of a partisan issue after Confederation in 1867, when the Liberals, drawing strong support from agrarians in the west, advocated tariff reductions. But the party was internally divided over trade and proved no match for the eastern-urban electoral strength of the Tories, who pushed through the protectionist "national policy" in $1878 .{ }^{133}$ Divisions among business groups, workers, and farmers hampered the development of class-based peak associations, and industry groups continued to play a very active role in policymaking. ${ }^{134}$ Class cleavages did, as expected, become more visible in the 1920 s and 1930 s, when radical agrarian movements in the western provinces challenged the protectionist policy endorsed by the major parties; but a series of concessions by King's Liberal government helped to check the conflict. ${ }^{135}$ In the years after 1945, with the parties (and peak associations) relying on heterogeneous combinations of regional, ethnic, and economic groups for support, the policymaking process was shaped more by "ins versus outs" than by simple class cleavages. ${ }^{136}$

In Australia the pattern looks very different. Levels of factor mobility rose precipitously from the 1870 s to the 1930 s and remained relatively high in later decades. According to the theory, we expect Australian trade politics to be marked by a fairly robust class cleavage, pitting owners of abundant land against urban interests, since late in the nineteenth century. ${ }^{137}$ Again, the evidence, summarized in Table 7 , suggests a reasonable fit.

After the colonies became self-governing in the 1850 s and 1860 s, debates over trade policy were characterized by fierce lobbying by local industry groups in each legislature, with different sets of manufacturers and workers taking opposing

132. Palmer 1983, 20. On the lobbying patterns, see Easterbrook and Aitken 1956, 291. Protectionist manufacturers formed the Association for the Promotion of Canadian Industry in 1858, but others countered by creating a Tariff Reform Association in the same year. Forster 1986, 35, 47.

133. On divisions within the parties, see Forster 1986, 175; and Easterbrook and Aitken 1956, 393-94.

134. On the difficulties faced by nascent labor organizations in these years, see Palmer 1983. On the Canadian Manufacturers' Association, see Coleman 1988, 22. On lobbying, see Forster 1986, 114; Coleman 1988, 20; and McLean 1895, 19.

135. The first agrarian attack came from the Progressive Party in the 1920 s, to which King responded by reducing duties on farm machinery and sales tax on all farm inputs. McDiarmid 1946, 264. The second attack came from the Cooperative Commonwealth Federation in the 1930s, in which farmers combined forces with radical labor groups. King responded this time with a program of farm subsidies and support for bilateral agreements with Britain and the United States.

136. This conclusion is Thorburn's. Thorburn 1985, 17, 338. On divisions over trade among farmers and among member unions in the Canadian Labor Congress, see Protheroe 1980, 36. The Canadian Manufacturing Association refused to take any general position on the trade issue.

137. Rogowski actually predicts that business joined farmers as advocates of freer trade in Australia beginning in the interwar period when measures indicate that the economy was capital abundant compared to world averages. Given the extent of bias in Australian trade flows toward Britain and later the United States, for political and historical reasons, we might question this. The economy was certainly capital scarce compared with its major trade partners. 


\section{TABLE 7. Anticipated and observed outcomes in Australia}

\begin{tabular}{|c|c|c|c|c|c|}
\hline Period & $\begin{array}{c}\text { Factor } \\
\text { endowments }\end{array}$ & Mobility & Prediction $^{\mathrm{a}}$ & $\begin{array}{l}\text { Outcomes: Class- } \\
\text { based parties and } \\
\text { associations }\end{array}$ & Industry groups \\
\hline $1815-69$ & $\begin{array}{l}\text { Abundant land; } \\
\text { scarce capital } \\
\text { and labor }\end{array}$ & Low & $\begin{array}{l}\text { Industry } \\
\text { coalitions }\end{array}$ & - & $\begin{array}{l}\text { Highly active; } \\
\text { many groups } \\
\text { testified before } \\
\text { committees on } \\
\text { trade policy and } \\
\text { petitioned state } \\
\text { assemblies }\end{array}$ \\
\hline $1870-1914$ & $\begin{array}{l}\text { Abundant land; } \\
\text { scarce capital } \\
\text { and labor }\end{array}$ & High & $\begin{array}{l}\text { Class } \\
\text { coalitions }\end{array}$ & $\begin{array}{l}\text { Protectionists and } \\
\text { Free Traders fought } \\
\text { over trade issue until } \\
\text { merger in } 1909 \text {; } \\
\text { Labor protectionist }\end{array}$ & $\begin{array}{l}\text { Fewer groups } \\
\text { actively lobbied } \\
\text { trade commissions }\end{array}$ \\
\hline 1919-1939 & $\begin{array}{l}\text { Abundant land } \\
\text { and capital; } \\
\text { scarce labor }^{\text {b }}\end{array}$ & High & $\begin{array}{l}\text { Class } \\
\text { coalitions }\end{array}$ & $\begin{array}{l}\text { Liberal-Country } \\
\text { coalition and Labor } \\
\text { both protectionist }\end{array}$ & $\begin{array}{l}\text { Little evidence of } \\
\text { lobbying on trade }\end{array}$ \\
\hline $1945-1994$ & $\begin{array}{l}\text { Abundant land } \\
\text { and capital; } \\
\text { scarce labor }\end{array}$ & High & $\begin{array}{l}\text { Class } \\
\text { coalitions }\end{array}$ & $\begin{array}{l}\text { Coalition and Labor, } \\
\text { along with AFB and } \\
\text { ACTU, committed to } \\
\text { protection; some } \\
\text { Country party dissent } \\
\text { in } 1980 \mathrm{~s}\end{array}$ & $\begin{array}{l}\text { Major groups } \\
\text { lobbied Tariff } \\
\text { Board for } \\
\text { alterations to rates }\end{array}$ \\
\hline
\end{tabular}

${ }^{a}$ Class coalitions are expected to imply that class-based organizations are internally unified on trade and adopt coherent platforms while groups are inactive. Industry coalitions imply that class-based organizations are internally divided on trade and adopt ambiguous positions (see Table 1).

${ }^{b}$ Here Rogowski's classification is problematic. The evidence on endowments employed by Rogowski compares factor proportions in each nation with world averages. Given the overwhelming bias in Australia's dependence on trade with Britain (for political and historical reasons) and, after 1945 , on trade with the United States, a strong case can be made for considering the economy to be scarce in capital relative to its main trading partners. Data from later years is consistent with this view. This leads us to predict that business (and the organizations representing them) would support protection, as the analysis here seems to confirm.

${ }^{\text {'Using }} 1966$ data, Bowen, Leamer, and Sveikauskas (1987) find Australia to be very scarce in capital-in contrast to Rogowski's findings-and in all types of labor (except agricultural workers) and abundant in arable land. 
positions. ${ }^{138}$ But the lines of cleavage were redrawn around the turn of the century. Urban "protection" leagues battled with rural "free trade" leagues in each colony during the 1890s and in the new federal Parliament after 1901, when they were transformed into the Protection and Free Trade parties. The Protectionists formed an uneasy governing coalition with Labor after 1903, but militancy among unions and Labor's growing electoral success eventually split them. In 1909 Protectionists and Free Traders formed an anti-Labor coalition, the Liberal party, that endorsed the prevailing high tariff and effectively shelved the trade issue. The protectionist compromise - as unique, in its own way, as Sweden's free-trade counterpartremained solidly in place in the decades that followed, as both sides voiced unified support for existing policy. ${ }^{139}$

\section{Conclusions and Implications}

The findings here have important implications for the analysis of trade politics and, more generally, for economic policymaking. They suggest that the types of political coalitions that take shape in society and organize to influence economic policymaking largely depend on one basic feature of the economic environment that may vary over time and across nations: the extent to which factors of production are mobile between industries. Although a number of scholars have discussed the possibility of relating variation in factor mobility to variation in coalitions, no systematic empirical exploration of the relationship has been attempted to date. ${ }^{140}$

The evidence reported here indicates that levels of factor mobility have varied considerably historically and cross-nationally among several Western economies, in line with different stages of industrialization and differences in regulation. The investigation of trade politics in each case reveals a strong correlation between general levels of inter-industry factor mobility and coalition formation. Overall, class coalitions appear stronger-that is, class-based parties and peak associations are more unified on trade-when levels of mobility are higher. Industry coalitions appear stronger-that is, lobby groups take a more active role in policymakingwhen levels of factor mobility are lower.

The findings may carry important implications for the likely character of trade policies. When the trade issue becomes a more internally divisive force in major parties and peak associations, party leaders will have an incentive to gravitate

138. See Serle 1971, 31-32; and Atkins 1958. When governments in Victoria and New South Wales set up select committees to investigate trade policy and the state of their economies in the 1860s, they were flooded with petitions and witnesses lobbying on both sides of the tariff issue. Patterson 1968, 12-14, 25. On divisions among labor, see Nairn 1957, 435-36.

139. See Cotter 1967. In the postwar years, the Liberal-Country coalition also took the position that, as long as foreign barriers to agricultural exports remained high, they were justified in maintaining high protection for domestic manufacturing and effectively opting out of GATT liberalizations (a position acceptable to rural exporters and business interests dependent on protection). Not coincidentally, they introduced a general program of subsidies aimed at farmers. Arndt 1965.

140. See Magee 1980; and Alt et al. 1996. 
toward incoherent positions aimed at balancing competing demands from the strongest groups on either side of the debate. Ambiguity in policy facilitates the compromise that becomes essential for party leaders faced with competing demands. This may describe developments in the United States and other Western economies in recent years, where leaders have used an array of nontariff instruments to undercut multilateral liberalization without actually abandoning the process.

There are reasons to be cautious about the findings here and what we can make of them. I have not controlled for other variables that might plausibly explain differences in coalition patterns and in the behavior of parties and groups. Variation in electoral and policymaking institutions are likely to have effects. Political organizations geared to representing broad types of coalitions are more likely when the franchise is extended more widely among society, for instance, and parties may be expected to act more cohesively, in general, in parliamentary systems and under proportional representation than they do in presidential systems and under plurality rule. ${ }^{141}$ Rogowski has argued that whether proportional representation encourages politicians to appeal to broader or more particularistic interests actually depends on how attached voters are to the parties (that is, how easily they can be "bought"). ${ }^{142}$ Daniel Verdier and James Alt and Michael Gilligan have argued that policymaking rules that allow more access and influence for lobby groups (say, during hearings by legislative committees) are less likely to encourage formation of broad class coalitions. $^{143}$

Certainly these arguments warrant more empirical investigation, aimed specifically at making sense of trade politics. It is highly unlikely, however, that they can explain all the variation we see in cleavages over trade policy. The broad urban-rural conflict that defined U.S. trade politics in the 1880 s and 1890 s, for instance, developed within the same institutional structure that allowed the infamous lobbying free-for-all over the Smoot-Hawley bill in 1930. In Britain, intense Left-Right partisanship on trade in the 1920 s gave way to internal bickering among groups and party factions at both ends of the spectrum by the $1960 \mathrm{~s}$, without a major change in institutions. ${ }^{144}$ Electoral and policymaking rules undoubtedly have important effects on trade politics. But the evidence presented here suggests that cleavages are

141. See Duverger 1954; LaPalombara and Weiner 1966; Cox 1987; and Turner and Schneier 1970. In the fuller version of the analysis, I have gone some way toward controlling for these effects by measuring levels of party cohesion in votes on trade legislation in each case relative to general party cohesion in all votes during the same legislative session.

142. Rogowski 1998 .

143. See Verdier 1994; and Alt and Gilligan 1994. Verdier's claim is part of a far more ambitious argument that attempts to endogenize policymaking institutions themselves by reference to the salience and divisiveness of the trade issue among voters. Though wonderfully provocative, Verdier's study does not attempt to test this argument empirically and encounters some real problems. The argument treats voter preferences over trade policy as exogenous, for instance, ignoring their origins, and yet considers the preferences of firms and unions to be endogenous to policymaking institutions. For an alternative argument (focusing on the origins of the U.S. Reciprocal Trade Agreements Act of 1934) about how trade policy coalitions can shape trade policymaking institutions, see Hiscox 1999.

144. For a detailed discussion of how several institutional arguments fare in explaining evidence from all six of the nations discussed here, see Hiscox 1997, chaps. 1, 8 and forthcoming. 
powerfully shaped by economic forces. The next step should be to specify just how cleavages and institutions interact to produce patterns in trade politics.

There are other reasons for proceeding with caution. The theory is based on a model of the economy that assumes competitive markets and no international movement of factors. Relaxing these assumptions creates a number of complications. We may expect, for instance, that as economies of scale become more important in production, not only do broad class coalitions become less likely in trade politics, but divisions may also emerge between individual firms within the same sector. ${ }^{145}$ Allowing that factors of production can be more or less mobile internationally would also require a significant reformulation of the theory. ${ }^{146}$ Also, no allowance has been made for variation in ownership structures in capital markets. In particular, deeper equity markets make it easier to trade ownership of capital assets in different industries and for owners of capital to diversify their portfolio of investments across industries. ${ }^{147}$ To the extent that capitalists own diversified portfolios, they should be less concerned about individual industry returns and how they are affected by trade and so less inclined to form industry-based coalitions in trade politics. ${ }^{148}$

Finally, since factor mobility clearly can be affected by regulations, we must question the degree to which it is endogenous to politics. Very little systematic research has been done on the political origins of restrictions on factor movements and adjustment assistance and other mobility-enhancing policies. ${ }^{149}$ Perhaps existing coalition patterns shape policies in ways that help determine future levels of

145. Individual firms may lobby on their own account or form ad hoc coalitions with firms from other industries with similar preferences. This pattern seems more common in recent years in the United States. The 1994 debates over the Uruguay Round of GATT, for instance, witnessed the formation of the Coalition of Service Industries, Intellectual Property Committee, and Alliance for GATT Now, all with diverse memberships of large firms.

146. For a formal treatment of this issue, see Hiscox 1998. Whether international factor mobility reinforces class or industry cleavages over trade turns out to depend on the degree of factor mobility between industries and whether factors located in different industries are differentially mobile between nations.

147. Williamson's analysis suggests that the development of equity markets in the twentieth century is actually related to increasing capital specificity (indicated by the profit data in Figure 1). When capital is less mobile between uses, we should expect greater reliance on equity financing rather than on borrowing, since lenders are more reluctant to invest in more specific assets and charge premiums for the added risks. Williamson 1985, 307-309. Meanwhile, as Mussa has pointed out, at lower levels of capital mobility, the negative correlation between returns to capital in export and import-competing industries provides an incentive for capital owners to diversify ownership across industries. Mussa 1974.

148. This raises some fundamental questions about the distinction between owners and managers and its political implications. Managers act only as agents for the capital invested in each firm. Since they, and the industry associations they form, make decisions about how much to spend on lobbying-and since they also comprise the direct memberships of business peak associations-it is not clear that we need to greatly modify the anticipated effects of variation in mobility outlined in Table 1. The implications for party behavior are perhaps less clear. To the extent that parties respond to group lobbying, the anticipated effects are unchanged; to the extent that they respond to preferences of capital-owning voters (who may own diversified portfolios), we should anticipate more unity on the trade issue.

149. Burgoon and Hiscox 2000. 
mobility-suggesting a sequence of cause and effect between cleavages and mobility that would introduce a more complicated, dynamic component to the analysis. Bargaining between broad class coalitions in Sweden, for instance, does appear to have shaped the broad retraining and adjustment programs that kept inter-industry mobility levels high in the postwar Swedish economy. Or perhaps some third force shapes both coalitions and factor mobility at the same time. This is Verdier's argument about the importance of electoral competition in determining the extent to which politicians try to appeal to broader rather than narrower coalitions (and hence the degree to which they favor mobility-enhancing policies). ${ }^{150}$

The data speak quite clearly to this endogeneity question. The evidence indicates that levels of factor mobility in Western economies have been powerfully affected by exogenous economic and technological changes associated with different stages of industrialization. That these changes in measured levels of mobility appear to be associated, in anticipated fashion, with changes in coalition patterns in trade politics suggests that this line of inquiry is worth pursuing with new energy.

\section{Appendix: Data Sources}

\section{United States}

The Weeks and Aldrich reports provide data on daily wage rates for workers in eighteen manufacturing industries in 1860 and thirteen in $1890 .^{151}$ Daily wage rates for twenty-one skilled occupations associated with different industries are recorded as decade averages for the period 1820 to $1880 .{ }^{152}$ Clarence Long also used Census of Manufactures ${ }^{153}$ data to calculate annual earnings for workers in seventeen manufacturing industries from 1860 to 1890 . I amended his original list slightly to extend the series for fifteen industries from 1820 to 1909 , and constructed a similar series for a broader set of twenty industries. After the turn of the century, of course, evidence is more readily available. ${ }^{154}$ Hourly wage rates for manual workers in the manufacturing industries classified at the two-digit SIC level are reported by the Department of Labor from 1947. In addition, the hourly rates for unskilled workers between 1920 and 1935 were recorded by the National Industrial Conference

150. Verdier 1995. Unfortunately, the vigorous mobility-enhancing policies in Sweden, employed by a Social Democratic government that dominated postwar politics, run counter to Verdier's "competition" thesis.

151. See Weeks 1886; and Aldrich 1893. Data from both reports are reproduced in Long 1960.

152. The data are from the Sixteenth Annual Report of the Bureau of Statistics of Labor, Massachusetts, 1885, and are reproduced in Mulhall 1899, 583.

153. Long 1960.

154. Specifically, "Liquors, malt" and "Chewing tobacco" were cut from the list used by Long; boots and shoes, machinery, hardware, clothing, and printing were added to make up the longer list. The data for $\mathbf{1 8 2 0}$ are for Pennsylvania only. For a thorough discussion of the weaknesses of the early census data on wages, and the comparative weaknesses of the Weeks and Aldrich reports, see Long 1960, 3-49. 
Board. ${ }^{155}$ Total annual earnings for production workers are also reported by industry by the Department of Commerce beginning in $\mathbf{1 8 9 9}$ for fifteen categories and from 1947 for nineteen categories. ${ }^{156}$

Data on rates of return to capital in different industries are even harder to come by for early periods than those on wages. For the longest historical series (from 1820 to 1919) I used data from the Census of Manufactures ${ }^{157}$ to calculate profits (value-added minus wage costs) as a percentage of capital invested in manufacturing industries. ${ }^{158}$ After 1919, the Census ceased reporting data on capital invested in industries, but from 1947 total man-hours per year are available for each industry, and $I$ have used profit per man-hour as a proxy for profit rates thereafter. ${ }^{159}$ Beginning in 1933, direct data are also available on corporation profits (as percentages of net worth and equity) by two-digit SIC industries from the Securities and Exchange Commission. ${ }^{160}$

\section{Britain}

Data on wages of skilled workers in the nineteenth century are drawn from Michael Mulhall and sources cited therein, and from Mitchell's British Historical Statistics. ${ }^{161}$ Data on the wages for technical and manual workers after 1915 are from the Central Statistical Office, British Labour Statistics: Historical Abstract. Further data are drawn from the ILO's Yearbook of Labour Statistics, and the UN's Industrial Statistics Yearbook. Data on value-added are drawn from the UN's Industrial Statistics Yearbook, which provides value-added data from 1953, and from Mitchell's British Historical Statistics, which reports census data from 1907.

\section{France}

Data on wages of skilled workers in the nineteenth century are drawn from Michael Mulhall and sources cited therein. ${ }^{162}$ Data on the wages of skilled workers between 1915 and 1935 are from the ILO's Yearbook of Labour Statistics; from 1915 on the yearbook provides hourly rates for workers in different industries. The series on manual labor wages is from the Annuaire statistique de la France. The UN's Industrial Statistics Yearbook provides value-added data from 1958.

155. The data are reported in Glasser 1940, 36.

156. Department of Commerce, Historical Statistics of the United States, and Statistical Abstract of the United States.

157. U.S. Securities and Exchange Commission, Corporation Profits, various years, and U.S. Department of Commerce, Statistical Abstract of the United States.

158. I used the same lists of fifteen and twenty manufacturing industries employed for the calculation of annual earnings of workers described earlier.

159. The latter follows Alt et al. 1999.

160. U.S. Securities and Exchange Commission, Corporation Profits, and U.S. Department of Commerce, Statistical Abstract of the United States.

161. See Mulhall 1899; and Mitchell 1988.

162. Ibid. 


\section{Sweden}

Data on the wages of male and female workers between 1860 and 1930 are from Gösta Bagge. ${ }^{163}$ I have also drawn data on wages from the ILO's Yearbook of Labour Statistics, and the UN's Industrial Statistics Yearbook. Douglas Hibbs and Hakan Locking provide further evidence on industry wage variation. ${ }^{164}$ Data on industry profits are from the UN's Industrial Statistics Yearbook, which provides value-added data from 1953.

\section{Canada}

Data for wages in the nineteenth century are from Urquhart's Historical Statistics of Canada. Further wage data are drawn from the ILO's Yearbook of Labour Statistics and the UN's Industrial Statistics Yearbook. Data on industry profits are from the UN's Industrial Statistics Yearbook, which provides value-added data from 1938, and from Historical Statistics of Canada, which provides data from 1870. Data on corporation profits and assets are from Statistics Canada, Corporation Financial Statistics.

\section{Australia}

Data for wages in the nineteenth century are drawn from the NSW Statistical Register. Data on hourly rates for workers are derived from the ILO's Yearbook of Statistics. Data on earnings are supplied from the UN's Industrial Statistics and from the Australian Bureau of Statistics, Manufacturing Establishments.

Data on value-added are from the UN's Industrial Statistics Yearbook and from the ABS's Manufacturing Establishments. Also, recent data on industry profits are derived from the Industry Assistance Commission's annual reports.

\section{References}

Aldrich, Nelson, W. 1893. Wholesale Prices, Wages, and Transportation. Report by the Secretary of the Treasury. 52nd Cong., 2nd sess., S.R. 1394. Washington, D.C.: U.S. Government Printing Office.

Alesina, Alberto. 1989. Politics and Business Cycles in Industrial Democracies. Economic Policy 8:55-87.

Alesina, Alberto, and Howard Rosenthal. 1995. Partisan Politics, Divided Government, and the Economy. Cambridge: Cambridge University Press.

Alt, James, and Michael Gilligan. 1994. The Political Economy of Trading States. Journal of Political Philosophy 2:165-92.

Alt, James, Jeffry Frieden, Michael Gilligan, Dani Rodrik, and Ronald Rogowski. 1996. The Political Economy of International Trade: Enduring Puzzles and an Agenda for Inquiry. Comparative Political Studies 29 (6):689-717.

163. Bagge 1936.

164. Hibbs and Locking 1996. 
Alt, James E., Fredrik Carlsen, Per Heum, and Kåre Johansen. 1999. Asset Specificity and the Political Behavior of Firms: Lobbying for Subsidies in Norway. International Organization 53 (1):99-116.

Anderson, R. Kym. 1980. The Political Market for Government Assistance to Australian Manufacturing Industries. Economic Record 56 (June):132-44.

Arndt, H. W. 1965. Australia: Developed, Developing, or Midway? Economic Record 41 (95): 318-40. Atkins, Barbara. 1958. Antecedents of the NSW Protectionist Party. Proceedings of the Royal Australian Historical Society 44:239-58.

Australian Bureau of Statistics. Various years. Manufacturing Establishments: Details of Operations by Industry Class. Canberra: Australian Bureau of Statistics.

Aydelotte, William O. 1962. Voting Patterns in the British House of Commons. Comparative Studies in Society and History 5:134-63.

Bagge, Gösta. 1936. Wages in Sweden, 1860-1930. Vol. 2 of Wages, Cost of Living, and National Income in Sweden, 1860-1930. London: P. S. King.

Baldwin, Robert E. 1985. The Political Economy of U.S. Import Policy. Cambridge, Mass.: MIT Press.

Bartel, Ann P., and Frank R. Lichtenberg. 1987. The Comparative Advantage of Educated Workers in Implementing New Technology. Review of Economics and Statistics 69 (1):1-11.

Bauer, Raymond A., Ithiel de Sola Pool, and Lewis Anthony Dexter. 1963. American Business and Public Policy: The Politics of Foreign Trade. New York: Atherton.

Beer, Samuel H. 1965. Modern British Politics: A Study of Parties and Pressure Groups. London: Faber.

Blank, Stephen. 1973. Industry and Government in Britain: The Federation of British Industries in Politics, 1945-1965. Lexington, Mass.: Lexington Books.

Bloch, Farrell E. 1979. Labor Turnover in U.S. Manufacturing Industries. Journal of Human Resources 14 (2):236-46.

Block, Richard N. 1978. The Impact of Seniority Provisions on the Manufacturing Quit Rate. Industrial and Labor Relations Review 31 (4):474-88.

Bowen, Harry, Edward E. Leamer, and Leo Sveikauskas. 1987. Multicountry, Multifactor Tests of the Factor Abundance Theory. American Economic Review 77 (5):791-809.

Boyce, Robert W. D. 1987. British Capitalism at the Crossroads, 1919-1932. Cambridge: Cambridge University Press.

Bradford, Sarah. 1984. Disraeli. New York: Stein and Day.

Brogan, Denis W. 1967. The Development of Modern France, 1870-1939. New York: Harper Brothers.

Brown, Benjamin H. 1943. The Tariff Reform Movement in Great Britain, 1881-1885. New York: Columbia University Press.

Burgoon, Brian, and Michael J. Hiscox. 2000. Trade Openness and Political Compensation: Labor Demands for Adjustment Assistance. Paper presented at the 96th Annual Meetings of the American Political Science Association, September, Washington, D.C.

Cain, Louis P., and Donald G. Patterson. 1986. Biased Technical Change, Scale, and Factor Substitution in American Industry, 1850-1919. Journal of Economic History 46 (1): 153-64.

Caron, Francois. 1979. An Economic History of Modern France. New York: Columbia University Press.

Carr, James C., and W. Taplin. 1962. History of the British Steel Industry. Cambridge, Mass.: Harvard University Press.

Caves, Richard E., and Michael E. Porter. 1979. Barriers to Exit. In Essays on Industrial Organization in Honor of Joe S. Bain, edited by Robert T. Masson and P. David Qualls, 39-69. Cambridge: Ballinger.

Caves, Richard E., Jeffrey A. Frankel, and Ronald W. Jones. 1990. World Trade and Payments: An Introduction. 5th ed. Glenview, Ill.: Scott Foresman.

Clapham, John. 1926-38. An Economic History of Modern Britain. Cambridge: Cambridge University Press.

Coleman, William D. 1988. Business and Politics: A Study of Collective Action. Kingston, Ont.: McGill-Queen's University Press.

Commons, John R. 1909. Horace Greeley and the Working Class Origins of the Republican Party. Political Science Quarterly 24 (3):468-88. 
Cotter, Richard. 1967. War, Boom, and Depression. In Essays in the Economic History of Australia, 1788-1939, edited by James Griffin, 244-82. Brisbane: Jacaranda.

Cox, Gary W. 1987. The Efficient Secret: The Cabinet and the Development of Political Parties in Victorian England. Cambridge: Cambridge University Press.

1997. Making Votes Count: Strategic Coordination in the World's Electoral Systems. Cambridge: Cambridge University Press.

Davis, Lance E., Jonathan R. T. Hughes, and Duncan M. McDougall. 1961. American Economic History:

The Development of a National Economy. Homewood, Ill.: Irwin.

Destler, I. M., and John Odell. 1987. Anti-Protection: Changing Forces in United States Trade Politics.

Washington, D.C.: Institute for International Economics.

Dunham, Arthur. 1930. The Anglo-French Treaty of Commerce of 1860 and the Progress of the Industrial Revolution in France. Ann Arbor: University of Michigan Press.

Dupeux, Georges. 1959. Le Front Populaire et les elections de 1936. Paris: A. Colin.

Duverger, Maurice. 1954. Political Parties: Their Organization and Activities in the Modern State. New York: Wiley.

Easterbrook, W. T., and Hugh G. J. Aitken. 1956. Canadian Economic History. Toronto, Ont.: Macmillan.

Edin, Per-Anders, and Johnny Zetterberg. 1992. Interindustry Wage Differentials: Evidence from Sweden and a Comparison with the United States. American Economic Review 82 (5):1341-49.

Elwitt, Sanford. 1975. The Making of the Third Republic: Class and Politics in France, 1868-1884. Baton Rouge: Louisiana State University Press.

Ethier, Wilfred. 1988. Modern International Economics. 2d ed. New York: W. W. Norton.

Fallon, P. R., and P. R. G. Layard. 1975. Capital-Skill Complementarity, Income Distribution, and Output Accounting. Journal of Political Economy 83 (2):279-302.

Fohlen, Claude. 1956. L'industrie textile au temps de Second Empire. Paris: Plon.

Foner, Eric. 1970. Free Soil, Free Labor, Free Men: The Ideology of the Republican Party Before the Civil War. New York: Oxford University Press.

Forster, Ben. 1986. A Conjunction of Interests: Business, Politics, and Tariffs 1825-1879. Toronto, Ont.: University of Toronto Press.

Frankel, Jeffrey A. 1992. Measuring International Capital Mobility: A Review. American Economic Review 82:197-202.

Freeman, Richard B. 1976. Individual Mobility and Union Voice in the Labor Market. American Economic Review 66:361-68.

- 1980. The Exit-Voice Tradeoff in the Labor Market: Unionism, Job Tenure, Quits, and Separations. Quarterly Journal of Economics (June):643-73.

Frieden, Jeffry A. 1991. Debt, Development, and Democracy: Modern Political Economy and Latin America, 1965-1985. Princeton, N.J.: Princeton University Press.

Friman, H. Richard. 1990. Patchwork Protectionism: Textile Trade Policy in the United States, Japan, and West Germany. Ithaca, N.Y.: Cornell University Press.

Galambos, Louis. 1979. The American Economy and the Reorganization of the Sources of Knowledge. In The Organization of Knowledge in Modern America, 1860-1920, edited by Alexandra Olson and John Voss, 269-82. Baltimore, Md.: Johns Hopkins University Press.

Gamble, A. M., and S. A. Walkland. 1984. The British Party System and Economic Policy, 1945-1983: Studies in Adversary Politics. Oxford: Clarendon Press.

Ganz, Gabriele. 1977. Government and Industry: The Provision of Financial Assistance to Industry and Its Control. Abingdon: Professional Books.

Geroski, P., and A. Jacquemin. 1985. Industrial Change, Barriers to Mobility, and European Industrial Policy. Economic Policy 1 (November):170-205.

Ghemawat, Panka, and Barry Nalebuff. 1990. The Devolution of Declining Industries. Quarterly Journal of Economics 105:167-86.

Gille, Bertrand. 1984. La siderurgie française au XIXe siecle. Geneva: Droz. 
Glasser, Carrie. 1940. Wage Differentials: The Case of the Unskilled. New York: Columbia University Press.

Goldin, Claudia, and Lawrence Katz. 1996. The Origins of Technology-Skill Complementarity. Quarterly Journal of Economics 113 (June):683-732.

Golob, Eugene. 1944. The Méline Tariff: French Agriculture and Nationalist Economic Policy. New York: Columbia University Press.

Gourevitch, Peter. 1986. Politics in Hard Times: Comparative Responses to International Economic Crises. Ithaca, N.Y.: Cornell University Press.

Grant, Wyn. 1980. Business Interests and the British Conservative Party. Government and Opposition 15 (2):143-61.

Griliches, Zvi. 1969. Capital-Skill Complementarity. Review of Economics and Statistics 51 (4):465-68.

Haggard, Stephan. 1988. The Institutional Foundations of Hegemony: Explaining the Reciprocal Trade Agreements Act of 1934. In The State and American Foreign Economic Policy, edited by G. John Ikenberry, David Lake, and Michael Mastanduno, 91-119. Ithaca, N.Y.: Cornell University Press.

Hall, Peter A. 1986. Governing the Economy: The Politics of State Intervention in Britain and France. Oxford: Oxford University Press.

Hamermesh, Daniel S. 1993. Labor Demand. Princeton, N.J.: Princeton University Press.

Hay, Donald A., and Derek J. Morris. 1984. Unquoted Companies: Their Contribution to the United Kingdom Economy. London: Macmillan.

Hayward, J. E. S. 1974. Steel. In Big Business and the State: Changing Relations in Western Europe, edited by Raymond Vernon, 255-71. Cambridge, Mass.: Harvard University Press.

Heckscher, Eli. 1954. An Economic History of Sweden. Cambridge, Mass.: Harvard University Press.

Heclo, Hugh, and Henrik Madsen. 1987. Policy and Politics in Sweden. Philadelphia: Temple University Press.

Helleiner, G. K. 1977. Transnational Enterprises and the New Political Economy of U.S. Trade Policy. Oxford Economic Papers 29 (1):102-16.

Hibbs, Douglas A., Jr. 1977. Political Parties and Macroeconomic Policy. American Political Science Review 71 (4): 1467-87.

Hibbs, Douglas, and Hakan Locking. 1996. Wage Dispersion and Productive Efficiency: Evidence for Sweden. Paper presented at the 92nd Annual Meetings of the American Political Science Association, San Francisco.

Hiscox, Michael J. 1996. Factor Mobility and Partisan Effects on U.S. Trade Votes. Paper presented at the Harvard/MIT Research Group on Positive Political Economy, MIT, Cambridge, Mass.

. 1997. The Trade War at Home: Factor Mobility, International Trade, and Political Coalitions in Democracies. Ph.D. diss., Harvard University.

- 1998. International Factor Mobility and Trade Politics. Paper presented at the 94th Annual Meetings of the American Political Science Association, Boston.

1999. The Magic Bullet? The RTAA, Institutional Reform, and Trade Liberalization. International Organization 53 (4):669-98.

- Forthcoming. International Trade and Political Conflict: Commerce, Coalitions, and Factor Mobility. Princeton, N.J.: Princeton University Press.

Holmlund, Bertil. 1984. Labor Mobility: Studies of Labor Turnover and Migration in the Swedish Labor Market. Stockholm: Industrial Institute for Economic and Social Research.

Hughes, Kent H. 1979. Trade, Taxes, and Transnationals: International Economic Decision Making in Congress. New York: Praeger.

International Labour Office. Various years. Yearbook of Labour Statistics. Geneva: International Labour Office.

Industry Assistance Commission. Various years. Annual Report. Canberra: Australian Government Publishing Service.

Irwin, Douglas A. 1995. Industry or Class Cleavages over Trade Policy? Evidence from the British General Election of 1923. NBER Working Paper 5170. Cambridge, Mass.: National Bureau of Economic Research. 
James, John A., and Jonathan S. Skinner. 1985. The Resolution of the Labor Scarcity Paradox. Journal of Economic History 45:513-40.

Jones, H. G. 1976. Planning and Productivity in Sweden. London: Croom Helm.

Jones, Ronald W. 1971. A Three-Factor Model in Theory, Trade, and History. In Trade, Balance of Payments, and Growth, edited by Jagdish Bhagwati, Ronald Jones, Robert A. Mundell, and Jaroslav Vanek, 3-21. Amsterdam: North-Holland.

Katz, Lawrence, and Lawrence Summers. 1989. Industry Rents: Evidence and Implications. Brookings Papers on Economic Activity: Microeconomics. Washington, D.C.: Brookings Institution.

Katzenstein, Peter J. 1985. Small States in World Markets: Industrial Policy in Europe. Ithaca, N.Y.: Cornell University Press.

King, Anthony, 1977. Britain Says Yes: The 1975 Referendum on the Common Market. Washington, D.C.: American Institute for Public Policy Research.

Krueger, Alan B., and Lawrence H. Summers. 1987. Reflections on the Inter-industry Wage Structure. In Unemployment and the Structure of Labor Markets, edited by Kevin Lang and Jonathan S. Leonard, 17-47. Oxford: Basil Blackwell.

- 1988. Efficiency Wages and the Inter-Industry Wage Structure. Econometrica 56 (2):259-93.

Krugman, Paul R., and Maurice Obstfeld. 1987. International Economics: Theory and Policy. Boston: Little Brown.

Landes, David S. 1969. The Unbound Prometheus: Technological Change and Industrial Development in Western Europe from 1750 to the Present. Cambridge: Cambridge University Press.

Lange, Peter, and Geoffrey Garrett. 1985. The Politics of Growth: Strategic Interaction and Economic Performance in the Advanced Industrial Democracies, 1974-1980. Journal of Politics 47 (3):792827.

LaPalombara, Joseph, and Myron Weiner. 1966. Political Parties and Political Development. Princeton, N.J.: Princeton University Press.

Lavergne, Real P. 1983. The Political Economy of U.S. Tariffs. New York: Academic Press.

Lawrence, Robert, and Barry Bosworth. 1987. Adjusting to Slower Economic Growth: The External Sector. In The Swedish Economy, edited by Barry P. Bosworth and Alice M. Rivlin, 55-88. Washington, D.C.: Brookings Institution.

Leamer, Edward E. 1984. Sources of International Comparative Advantage: Theory and Evidence. Cambridge, Mass.: MIT Press.

Lindbeck, Assar. 1974. Swedish Economic Policy. Berkeley: University of California Press.

Lipset, Seymour Martin, and Stein Rokkan. 1967. Party Systems and Voter Alignments: Cross-National Perspectives. New York: Free Press.

Long, Clarence D. 1960. Wages and Earnings in the United States, 1860-1890. Princeton, N.J.: Princeton University Press.

Lowe, Marvin E. 1942. The British Tariff Movement. Washington, D.C.: American Council on Public Affairs.

Lubenow, W. C. 1988. Parliamentary Politics and the Home Rule Crisis: The British House of Commons in 1886. Oxford: Clarendon Press.

Lundberg, Erik. 1985. The Rise and Fall of the Swedish Model. Journal of Economic Literature 23 (1): $1-36$.

Mabbett, Deborah. 1995. Trade, Employment, and Welfare: A Comparative Study of Trade and Labour Market Policies in Sweden and New Zealand, 1880-1980. New York: Oxford University Press.

Magee, Stephen P. 1980. Three Simple Tests of the Stolper-Samuelson Theorem. In Issues in International Economics, edited by Peter Oppenheimer, 138-53. London: Oriel.

Magnus, Philip M. 1954. Gladstone: A Biography. London: Murray.

Marrison, A. J. 1983. Businessmen, Industries, and Tariff Reform in Great Britain. Business History 25 (2): $148-78$.

Martin, Albro. 1992. Railroads Triumphant: The Growth, Rejection, and Rebirth of a Vital American Force. Oxford: Oxford University Press.

Mayer, Wolfgang. 1984. Endogenous Tariff Formation. American Economic Review 74 (5):970-85. 
McCord, Norman. 1958. The Anti-Corn Law League, 1838-1846. London: Allen Unwin.

McDiarmid, Orville J. 1946. Commercial Policy in the Canadian Economy. Cambridge, Mass.: Harvard University Press.

McKenzie, Robert. 1963. British Political Parties. 2d ed. London: Heinemann.

McLean, Simon J. 1895. The Tariff History of Canada. Toronto: Warwick Bros. Rutter.

Midford, Paul. 1993. International Trade and Domestic Politics: Improving on Rogowski's Model of Political Alignments. International Organization 47 (4):535-64.

Milner, Helen V. 1988. Resisting Protectionism: Global Industries and the Politics of International Trade. Princeton, N.J.: Princeton University Press.

Milner, Henry. 1989. Sweden: Social Democracy in Practice. Oxford: Oxford University Press.

Mincer, Jacob. 1984. Human Capital and Economic Growth. Economics of Education Review 3:195-205.

Mitchell, Brian R. 1988. British Historical Statistics. New York: Cambridge University Press.

Mitchell, Olivia S. 1982. Fringe Benefits and Labor Mobility. Journal of Human Resources 17 (2):286-98.

Montgomery, Arthur. 1939. The Rise of Modern Industry in Sweden. London: P. S. King.

Mulhall, Michael G. 1899. The Dictionary of Statistics. 4th ed. London: Routledge Sons.

Mussa, Michael. 1974. Tariffs and the Distribution of Income. Journal of Political Economy 82 (6): 1191-1203.

. 1982. Imperfect Factor Mobility and the Distribution of Income. Journal of International Economics 12 (1):125-41.

Mytelka, Lynn Krieger. 1982. The French Textile Industry: Crisis and Adjustments. In The Emerging International Economic Order, edited by Harold K. Jacobson and Dusan Sidjanski, 129-66. Beverly Hills, Calif.: Sage.

Nairn, N. B. 1957. Rise of the Trades and Labour Council. Historical Studies of Australia and New Zealand 28.

Nairn, Tom. 1972. The Left Against Europe? New Left Review 75:5-120.

Naudin, Jean. 1928. Les accords commerciaux de la France depuis la guerre. Paris: Recueil Sirey.

North, Douglass. 1965. The Role of Transportation in the Economic Development of North America. Les grandes maritimes voies dans le monde XVe-XIXe siècles. Colloque international d'histoire maritime Vienne. Paris: S.E.V.P.E.N.

North, Douglass C., and Robert Paul Thomas. 1973. The Rise of the Western World. Cambridge: Cambridge University Press.

O'Brien, Patrick, ed. 1983. Railways and the Economic Development of Western Europe, 1830-1914. London: Macmillan.

Oi, Walter Y. 1962. Labor as a Quasi-Fixed Factor. Journal of Political Economy 70 (6):538-55.

Olson, Mancur. 1982. The Rise and Decline of Nations. New Haven, Conn.: Yale University Press.

Ostrogorski, Moisei. 1902. Democracy and the Organization of Political Parties. Trans. F. Clarke. New York: Macmillan.

Palmer, Bryan D. 1983. Working Class Experience: The Rise and Reconstitution of Canadian Labour, 1800-1980. Toronto: Butterworth.

Parsons, Donald U. 1972. Specific Human Capital: An Application to Quit Rates and Layoff Rates. Journal of Political Economy 80 (6):1120-43.

Pastor, Robert A. 1980. Congress and the Politics of U.S. Foreign Economic Policy, 1929-1976. Berkeley: University of California Press.

Patterson, Gordon D. 1968. The Tariff in the Australian Colonies, 1856-1900. Melbourne: Cheshire.

Pincus, Jonathan J. 1977. Pressure Groups and Politics in Antebellum Tariffs. New York: Columbia University Press.

Pontusson, Jonas, and Peter Swenson. 1993. Markets, Production, Institutions, and Politics: Why Swedish Employers Have Abandoned the Swedish Model. Paper prepared for the 8th Conference of Europeanists, Council of European Studies, Chicago, March.

Pratt, Edwin A. 1912. A History of Inland Transport and Communication in England. London: Paul, Trench, Trubner. 
Priouret, Roger. 1963. Origines du patronat français. Paris: Grasset.

Protheroe, David R. 1980. Imports and Politics: Trade Decision-Making in Canada, 1968-1979. Montreal: Institute for Research on Public Policy.

Ragan, James F., Jr. 1984. Investigating the Decline in Manufacturing Quit Rates. Journal of Human Resources 19:53-71.

Rehn, Gösta. 1985. Swedish Active Labor Market Policy: Retrospect and Prospect. Industrial Relations 24 (1):62-89.

Reich, Leonard S. 1985. The Making of American Industrial Research: Science and Business at GE and Bell, 1876-1926. Cambridge: Cambridge University Press.

Rempel, Richard A. 1972. Unionists Divided: Arthur Balfour, Joseph Chamberlain, and the Unionist Free Traders. Hamden, Conn.: Archon Books.

Republique française, Ministere des finances et des affairs economiques, Institut national de la statistique et des etudes economiques. Various years. Annuaire statistique de la France. Paris: Presses universitaires de France.

Rivlin, Alice M. 1987. Overview. In The Swedish Economy, edited by Barry P. Bosworth and Alice M. Rivlin, 1-21.Washington, D.C.: Brookings Institution.

Rogowski, Ronald. 1989. Commerce and Coalitions: How Trade Affects Domestic Political Alignments. Princeton, N.J.: Princeton University Press.

—_- 1998. Electoral Systems and Vote-Buying: Why PR Works Best When Voters Are Loyal, Majoritarian Systems When Voters are Fickle. Unpublished manuscript, University of California, Los Angeles.

Rose, Richard. 1980. Politics in England: An Interpretation for the 1980s. 3d ed. Boston: Little, Brown.

Ross, Arthur M. 1958. Do We Have a New Industrial Feudalism? American Economic Review 48 (5):903-20.

Russell, Dean. 1969. Frederic Bastiat: Ideas and Influence. New York: Foundation for Economic Education.

Rustow, Dankwart A. 1955. The Politics of Compromise: A Study of Parties and Cabinet Government in Sweden. Princeton, N.J.: Princeton University Press.

Safran, William. 1985. The French Polity. 2d ed. New York: Longman.

Sainsbury, Diane. 1980. Swedish Social Democratic Ideology and Electoral Politics 1944-1948. Stockholm: Almqvist Wiksell International.

Samuelson, Paul. 1971. Ohlin Was Right. Swedish Journal of Economics 73 (4):365-84.

Sauvy, Alfred. 1984. Histoire economique de la France entre les deux guerres. Paris: Economica.

Sawyer, John E. 1954. The Social Basis of the American System of Manufacturing. Journal of Economic History 14 (4):361-79.

Schattschneider, E. E. 1935. Politics, Pressures, and the Tariff. Englewood Cliffs, N.J.: Prentice-Hall.

Scherer, F. M. 1980. Industrial Market Structure and Economic Performance. $2 \mathrm{~d}$ ed. Chicago: Rand McNally.

Schonhardt-Bailey, Cheryl. 1991. Specific Factors, Capital Markets, Portfolio Diversification, and Free Trade. World Politics 43 (4):545-69.

Semmel, Bernard. 1960. Imperialism and Social Reform: English Social-Imperial Thought, 1895-1914. London: Allen and Unwin.

Serle, Geoffrey. 1971. The Rush to Be Rich: A History of the Colony of Victoria, 1883-89. Melbourne: Melbourne University Press.

Shonfield, Andrew. 1965. Modern Capitalism: The Changing Balance of Public and Private Power. New York: Oxford University Press.

Sjoblom, G. 1985. The Roles of Political Parties in Denmark and in Sweden, 1970-84. Copenhagen: Institute of Political Studies.

Smith, Michael Stephen. 1980. Tariff Reform in France, 1860-1900. Ithaca, N.Y.: Cornell University Press. 
Sokoloff, Kenneth L. 1984. Was the Transition from the Artisanal Shop to the Nonmechanized Factory Associated with Gains in Efficiency? Evidence from the U.S. Manufacturing Censuses of 1820 to 1850. Explorations in Economic History 21 (4):351-82.

- 1986. Productivity Growth in Manufacturing During Early Industrialization. In Long-Term Factors in American Economic Growth, edited by Stanley L. Engerman and Robert E. Gallman; 679-736. Chicago: University of Chicago Press.

Stanwood, Edward. 1903. American Tariff Controversies in the Nineteenth Century. 2 vol. Boston: Houghton Mifflin.

Statistics Canada. Various years. Corporation Financial Statistics. Ottawa: Census and Statistics Office.

Stewart, Charles H., III. 1991. Lessons from the Post-Civil War Era. In The Politics of Divided Government, edited by Gary W. Cox and Samuel Kernell, 203-38 Boulder, Colo.: Westview Press.

Stolper, Wolfgang F., and Paul A. Samuelson. 1941. Protection and Real Wages. Review of Economic Studies 9 (1):58-73.

Taussig, Frank W. 1931. The Tariff History of the United States. 8th ed. New York: G. P. Putnam's Sons. Taylor, George. 1951. The Transportation Revolution, 1815-1860. New York: Rinehart.

Thorburn, Hugh G., ed. 1985. Party Politics in Canada. 5th ed. Scarborough, Ont.: Prentice-Hall.

Toynbee, Arnold. [1884] 1958. The Classical Definition of the Industrial Revolution. In The Industrial Revolution in Britain, edited by Philip A. M. Taylor, 1-6. Lexington, Mass.: Heath.

Turner, John. 1984. Businessmen and Politics: Studies of Business Activity in British Politics, 19001945. London: Heinemann.

Turner, Julius, and Edward V. Schneier, Jr. 1970. Party and Constituency. Rev. ed. Baltimore, Md.: Johns Hopkins University Press.

U.K. Department of Employment, Central Statistical Office. 1971. British Labour Statistics: Historical Abstract. London: H.M. Stationery Office.

United Nations. Various years. Industrial Statistics Yearbook. New York: Department of Economic and Social Affairs, Statistical Office of the United Nations.

Urquhart, Malcolm C. 1965. Historical Statistics of Canada. Cambridge: Cambridge University Press. U.S. Securities and Exchange Commission. Various years. Survey of American Listed Corporations. Corporation Profits. Washington, D.C.: U.S. Government Printing Office.

U.S. Department of Commerce, Bureau of the Census. Various years. Statistical Abstract of the United States. Washington, D.C.: U.S. Government Printing Office.

U.S. Department of Commerce, Bureau of the Census. 1976. Historical Statistics of the United States: Colonial Times to 1970. Washington, D.C.: U.S. Government Printing Office.

Verdier, Daniel. 1994. Democracy and International Trade: Britain, France, and the United States, 1860-1990. Princeton, N.J.: Princeton University Press.

- 1995. The Politics of Public Aid to Private Industry: The Role of Policy Networks. Comparative Political Studies 28 (1):3-40.

Verney, Douglas V. 1957. Parliamentary Reform in Sweden, 1866-1921. Oxford: Clarendon Press.

Victorian Registrar-General's Office. Various years. The Statistical Register of Victoria. Melbourne: Ferres.

Weaver, R. Kent. 1987. Political Foundations of Swedish Economic Policy. In The Swedish Economy, edited by Barry P. Bosworth and Alice M. Rivlin, 289-317. Washington, D.C.: Brookings Institution.

Weeks, Joseph D. 1886. Report on the Statistics of Wages in Manufacturing Industries with Supplementary Reports. Washington, D.C.: U.S. Government Printing Office.

Williamson, Oliver E. 1985. The Economic Institutions of Capitalism: Firms, Markets, Relational Contracting. New York: Free Press.

Wright, Gordon. 1964. Rural Revolution in France. Stanford, Calif.: Stanford University Press.

Young, Stephen, and A. V. Lowe. 1974. Intervention in the Mixed Economy: The Evolution of British Industrial Policy, 1964-72. London: Croom Helm.

Zebel, Sydney. 1940. Fair Trade: An English Reaction to the Breakdown of the Cobden Treaty System. Journal of Modern History 12 (2):161-85. 